\title{
Five primary sources of organic aerosols in the urban atmosphere of Belgrade (Serbia)
}

\author{
Roberta Zangrando ${ }^{\mathrm{a}, *}$, Elena Barbaro ${ }^{\mathrm{a}, \mathrm{b}}$, Torben Kirchgeorg ${ }^{\mathrm{a}, \mathrm{b}, \mathrm{c}}$, Marco Vecchiato ${ }^{\mathrm{a}, \mathrm{b}}$, Elisa Scalabrin ${ }^{\mathrm{b}}$, \\ Marta Radaelli ${ }^{\mathrm{b}}$, Dragana Đorđević ${ }^{\mathrm{d}}$, Carlo Barbante ${ }^{\mathrm{a}}$, Andrea Gambaro ${ }^{\mathrm{a}, \mathrm{b}}$ \\ a Institute for the Dynamics of Environmental Processes CNR, Via Torino 155, 30170 Mestre, (VE), Italy \\ b Department of Environmental Sciences, Informatics and Statistics, Ca' Foscari University of Venice, Via Torino 155, 30170 Mestre, (VE), Italy \\ c Institute of Sustainable and Environmental Chemistry, Leuphana University of Lüneburg, Lüneburg 21335, Germany \\ d Institute of Chemistry, Technology and Metallurgy - Centre of Chemistry, University of Belgrade, 11158 Belgrade, Serbia
}

\section{H I G H L I G H T S}

- Belgrade aerosols are affected by five primary sources.

- The increase of the levoglucosan/ mannosan ratio characterizes the open fire period.

- The enantiomeric ratio $(D / L)$ value for amino acids is higher in open combustions.

- Tracers from wood and other matrices involved in combustions help discerning events.

\section{GRA P H I C A L A B S T R A C T}

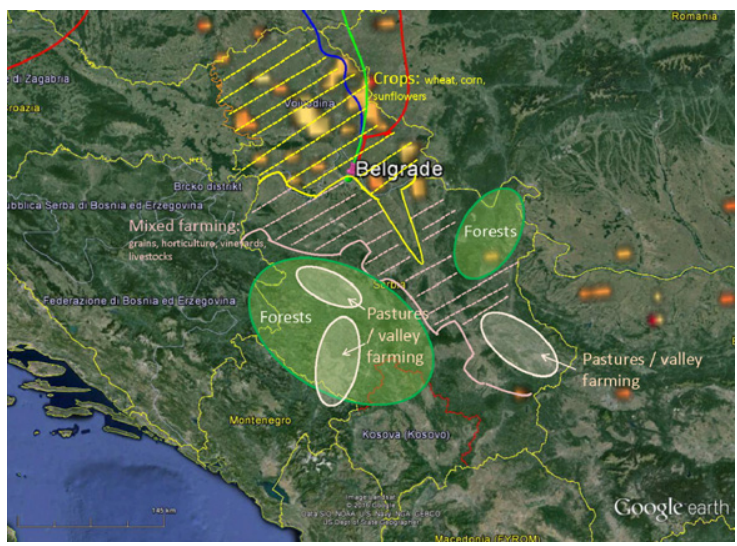

\section{A R T I C L E I N F O}

\section{Article history:}

Received 23 February 2016

Received in revised form 26 May 2016

Accepted 22 June 2016

Available online 21 July 2016

Editor: D. Barcelo

\section{Keywords:}

PMF

Aerosol primary sources

Biomass burning

PBAPs

Urban aerosols

\begin{abstract}
A B S T R A C T
Biomass burning and primary biological aerosol particles (PBAPs) represent important primary sources of organic compounds in the atmosphere. These particles and compounds are able to affect climate and human health. In the present work, using HPLC-orbitrapMS, we determined the atmospheric concentrations of molecular markers such as anhydrosugars and phenolic compounds that are specific for biomass burning, as well as the concentrations of sugars, alcohol sugars and D- and L-amino acids (D-AAs and L-AAs) for studying PBAPs in Belgrade (Serbia) aerosols collected in September-December 2008. In these samples, high levels of all these biomarkers were observed in October. Relative percentages of vanillic $(\mathrm{V})$, syringic compounds $(\mathrm{S})$ and p-coumaric acid $(\mathrm{PA})$, as well as levoglucosan/mannosan (L/M) ratios, helped us discriminate between open fire events and wood combustion for domestic heating during the winter. L-AAs and D-AAs ( $1 \%$ of the total) were observed in Belgrade aerosols mainly in September-October. During open fire events, mean D-AA/L-AA (D/L) ratio values of aspartic acid, threonine, phenylalanine, alanine were significantly higher than mean $\mathrm{D} / \mathrm{L}$ values of samples unaffected by open fire. High levels of AAs were observed for open biomass burning events.

Thanks to four different statistical approaches, we demonstrated that Belgrade aerosols are affected by five sources: a natural source, a source related to fungi spores and degraded material and three other sources linked
\end{abstract}

\footnotetext{
* Corresponding author.

E-mail address: roberta.zangrando@idpa.cnr.it (R. Zangrando).
} 
to biomass burning: biomass combustion in open fields, the combustion of grass and agricultural waste and the combustion of biomass in stoves and industrial plants. The approach employed in this work, involving the determination of specific organic tracers and statistical analysis, proved useful to discriminate among different types of biomass burning events.

\section{Introduction}

Primary sources emit water-soluble organic compounds directly into the atmosphere; the contributions of biomass burning and biological material are among the most relevant ones.

Biomass burning represents the largest source of primary fine carbonaceous matter, the second most important source of gases (Akagi et al., 2011; Calvo et al., 2013) and an important emitter of toxic compounds in the atmosphere (Lemieux et al., 2004; Naeher et al., 2007; Torres-Duque et al., 2008). In addition, biomass burning aerosols influence the climate by affecting the solar balance of the Earth (Hobbs et al., 1997; Carmichael et al., 2009), by influencing snow albedo (Stocker et al., 2013; Flanner et al., 2007; Ramanathan and Carmichael, 2008), and by acting as cloud condensation nuclei (Novakov and Corrigan, 1996; Vestin et al., 2007).

Biomass burning includes both natural and anthropogenic (Akagi et al., 2011; Calvo et al., 2013) sources: open fires in forests, savannas, deforestation, shifting cultivation, and burning of agricultural waste. Although volcanic activities and lightning may cause the ignition of forest fires, humans are generally the starting source of ignition, whether deliberately or accidentally (Taylor, 2010). Moreover, biomass represents an energy source exploited by humans for domestic heating and cooking.

In the atmosphere, sources of primary biological aerosol particles (PBAPs) include biological materials such as microorganisms, fungal spores, bacteria, viruses, pollen, dispersal units, fragments of plants, cells and animals, and excretions from biological organisms (Despres et al., 2012). PBAPs are ubiquitous and are emitted directly into the atmosphere. Bioaerosol can contribute $20-30 \%$ of the total atmospheric particulate matter $(>0.2 \mu \mathrm{m})$ (Chen et al., 2013) and, in the Amazonian region, it can represent $85 \%$ of the mass of coarse particles (Poeschl et al., 2010).

PBAPs influence the climatic system by acting as cloud condensation nuclei and as ice nuclei. There are also indications of their importance in the cloud water cycle (Manninen et al., 2014) (and references therein). Bioaersols are aerodynamically buoyant and can be transported over long distances (Despres et al., 2012), thereby contributing to the diffusion of trace elements and pathogens far from their original location (Yang et al., 2012) (and references therein).

PBAPs also affect humans, animals and vegetation. Pollen and fungal spores are responsible for allergies in humans (Manninen et al., 2014), especially in the spring. The composition and abundance of PBAPs in the atmosphere are related to season, meteorological conditions (temperature and humidity are the most important factors), geographical location and human activities (Manninen et al., 2014; Yang et al., 2012) (and references therein).

In the present work, we determined the atmospheric concentration of organic tracers that are specific of biomass burning: phenolic compounds (syringic acid (SyA), isovanillic acid, homovanillic acid (HA), p-coumaric acid (PA), coniferyl aldehyde (CAH), vanillic acid (VA), vanillin (VAN), syringaldehyde (SyAH) and ferulic acid (FA)) (Simoneit, 2002) and anhydrosugars (levoglucosan, mannosan and galactosan). We also determined other compounds related to PBAPs as sugars (arabinose, mannose, xylose, galactose, glucose, fructose and sucrose), alcohol sugars (xylitol, arabitol, ribitol, sorbitol and galactitol, mannitol, glycerol, erythritol, maltitol) (Medeiros et al., 2006; Simoneit et al., 2004) and D- and L-AAs (L-Ala, L-Asp, L-Asn, L-Arg, L-Glu, L-Phe, L-
Pro, L-Tyr, L-Thr, L-Hys, L-Lys, L-Leu/Ile, L-Orn, L-Ser, L-Gln, L-Val, Gly, D-Ala, D-Asp, D-Phe, D-Ser, and D-Thr) (Ge et al., 2011). Although biomass combustion often produces compounds such as sugars and alcoholsugars, these are also related to PBPAs (Jia et al., 2010b) (and references therein).

Phenolic compounds (PCs) are produced during biomass burning processes based on lignin combustion (Simoneit, 2002). Lignin is a biopolymer that is composed of three different aromatic alcohols: $p$ coumaryl, coniferyl and sinapyl alcohols. Their proportions differ among the major plant classes. The degradation products from the oxidation or burning of lignin are classified as coumaryl, vanillyl and syringyl moieties (Simoneit, 2002). In atmospheric aerosols, PCs may indicate the types of burned plants. Softwoods (gymnosperms) (Oros and Simoneit, 2001a) contain high proportions of coniferyl alcohol and minor proportions of sinapyl alcohol, and wood combustion produces primarily vanillyl moieties. The dominant PCs produced are vanillin, homovanillic acid, vanillic acid, and homovanillyl alcohol. Hardwood (angiosperm) lignin (Oros and Simoneit, 2001b) is enriched in sinapyl alcohol precursors, the combustion of these plants principally produces syringyl and vanillyl moieties. In deciduous tree smoke, the main methoxy phenols produced include homovanillyl alcohol, vanillic acid, vanillin, and syringic acid. In grasses (gramineae) (Oros et al., 2006), p-coumaryl alcohol is the prevalent lignin unit. Other significant products from burning grasses are acetosyringone, syringic acid, vanillin and vanillic acid.

Sugars can derive from numerous sources. Cellulosic material combustion produces anhydrosugars, which are specific markers of biomass burning (Simoneit, 2002) in the atmosphere. The combustion of hemicellulose generates high quantities of levoglucosan (from cellulose) and lower amounts of mannosan and galactosan.

Primary saccharides are produced from microorganisms, plants, animals, lichens, and bacteria (Dahlman et al., 2003; Simoneit et al., 2004; Yttri et al., 2007), while alcohol sugars come from fungal spores, bacteria, and lower plants (Bauer et al., 2008; Medeiros et al., 2006). Biomass burning is a source of saccharides (Di Filippo et al., 2013; Medeiros and Simoneit, 2008; Pio et al., 2008) due to the breakdown of polysaccharides and to the hydrolysis of anhydrosugars (Pio et al., 2008). It was also proposed as potential origin of fungal spores in urban areas. Sugars from soils and associated biota can be emitted in the atmosphere through re-suspension, erosion and agricultural activities (Jia et al., 2010a; Medeiros and Simoneit, 2007; Simoneit et al., 2004). Glucose, fructose and sucrose may derive from plant pollen and developing leaves (Fu et al., 2012; Graham et al., 2003; Pashynska et al., 2002). Arabitol and mannitol are described as molecular markers for fungal spores (Bauer et al., 2008; Burshtein et al., 2011; Di Filippo et al., 2013; Elbert et al., 2007) reflecting the contribution of microbially degraded material during the leaf senescence period and the fungal reproduction season (Medeiros et al., 2006; Pashynska et al., 2002). Their concentrations can be enhanced by biomass burning (Di Filippo et al., 2013).

AAs are an important class of compounds originating from biological, terrestrial and marine organisms (Ge et al., 2011). In general, LAAs are associated to animals, terrestrial plants and phytoplankton (Cowie and Hedges, 1992), and are used as primary production molecular markers. Gly is one of the most stable AAs (McGregor and Anastasio, 2001). In the atmosphere, Gly suggests a more aged aerosol (Samy et al., 2013) correlated to long-range transport (Barbaro et al., 
2011; Samy et al., 2013). D-AAs are used as markers of bacterial material both in terrestrial and marine environments (bacterioplankton) (Friedman, 2010; Kaiser and Benner, 2008; McCarthy et al., 1998). Enantiomeric $\mathrm{D} / \mathrm{L}$ ratios are used as indicators of bacterial origin. Indeed, peptidoglycan in microbial cellular walls contains a high proportion of D-Ala, D-Asp, D-Glu and D-Ser (Dittmar et al., 2001; McCarthy et al., 1998). Due to their low volatility, AAs have been observed in condensed phases such as particulate matter (Barbaro et al., 2011; Barbaro et al., 2015; Di Filippo et al., 2014; Matsumoto and Uematsu, 2005; Scalabrin et al., 2012), dew (Scheller, 2001), rain (Mace et al., 2003b; Mace et al., 2003c), fog (Zhang and Anastasio, 2003), microlayer (Kuznetsova et al., 2004; Matrai et al., 2008), lakes (Barbaro et al., 2014) and marine waters (Kuznetsova et al., 2004; Matrai et al., 2008; Sommerville and Preston, 2001).

In this study we developed two new analytical methods to determine anhydrosugars and PCs using HPLC-orbitrap MS. The aim of this work was to better understand how primary sources, such as biomass burning and PBAPs, affect the chemical composition of particulate matter during the seasonal transition from late summer to early winter in an urban environment. We performed this task by determining organic biomarkers. Moreover, we performed a source apportionment in order to assess the contribution of the studied primary sources and to highlight possible differences in the origins of the contributors to the particulate matter. We performed this study in Belgrade, an urban site where information on water-soluble organic compounds are scarce despite the importance of a source such as biomass burning (Glavonjic, 2011; Glavonjic and Oblak, 2012).

\section{Experimental}

\subsection{Aerosol sampling}

Because the aim of this work was to study biomass burning, PBAPs sources and their changes during the transition between last summer and winter, aerosols samples were collected between September and December 2008 in the urban area of Belgrade, Serbia $\left(44^{\circ} 49^{\prime} 14^{\prime \prime} \mathrm{N}\right.$, $20^{\circ} 27^{\prime} 44^{\prime \prime} \mathrm{E}$ ) in order to cover the seasonal change. The sampling was performed over a $24 \mathrm{~h}$ period, every 6 days, from 1 September to 30 November. From 1 to 12 December, the sampling was performed every $12 \mathrm{~h}$. In order to compare December samples to those collected from September to November, the compound concentrations in the two samples collected each day were added together considering a sampling time of $24 \mathrm{~h}$.

The temperature ranged between $3{ }^{\circ} \mathrm{C}$ (10 December) and $28^{\circ} \mathrm{C}(7$ September), with an average temperature of about $13^{\circ} \mathrm{C}$. The average pressure was $1016.18 \mathrm{hPa}$ and the average humidity was $67.9 \%$. The prevailing winds blew from NW, with an average wind speed of $3.5 \mathrm{~m} \mathrm{~s}^{-1}$. Daily meteorological data are in Table S3.

Total suspended particles (TSP) were collected on a pre-combusted ( $4 \mathrm{~h}$ at $400{ }^{\circ} \mathrm{C}$ in a muffle furnace) circular quartz fiber filter (QFF) (SKC Inc., Eighty Four, To-13 model) using a TE 5000 High Volume Air Sampler (Tisch Environmental Inc., OH, USA). In order to check for possible contamination, blank samples were collected by placing filters in the holder when the instrument was turned off. Samples and field blanks were stored at $-20^{\circ} \mathrm{C}$ in aluminum foil envelopes until analysis. The list of materials used in this work is reported in the supplementary information.

\subsection{Sample processing}

All sample preparations were performed under a class-1000 clean bench to avoid contamination. The pre-analytical protocol for the determination of anhydrosugars, PCs, AAs and sugars was performed as previously described (Perrone et al., 2012). Briefly, a 3/8 portion of each QFF was broken up into small pieces and placed in a $50 \mathrm{~mL}$ conical flask using steel tweezers, and the internal standard solution was spiked to the filter. The internal standard solution contained $70 \mathrm{ng}$ of ${ }^{13} \mathrm{C}_{6}$ vanillin, 1500 ng of ${ }^{13} \mathrm{C}_{6}$ levoglucosan and $200-300$ ng of ${ }^{13} \mathrm{C}$ AA mixture (Ala*, Arg*, and Glu*). The filter was ultrasonically extracted ( 2 cycles of $15 \mathrm{~min}$ with $5 \mathrm{~mL}$ and $2 \mathrm{~mL}$ of ultrapure water) and filtered through a $0.45 \mu \mathrm{m}$ PTFE filter (Phenomenex) before instrumental analysis.

\subsection{Instrumental methods}

Anhydrosugars were determined using HPAEC-(-)-APCIOrbitrapMS; PCs, using HPLC-(-)-ESI-OrbitrapMS; AAs, using HPLC$(+)$-ESI-orbitrapMS; and mono-, di-saccharides and alcohol sugars were determined using HPAEC-(-)-ESI-MS. All the details regarding instrumental methods and quality control are reported in the supplementary information.

\subsection{Back-trajectory calculation}

Back-trajectories were calculated using the Hybrid Single Particle Lagrangian Integrated Trajectory (HYSPLIT) transport and dispersion model (Draxler and Rolph, 2012). All back-trajectories (24 h) used GDAS Meteorological Data and vertical velocity model and were calculated at 200, 500, $1000 \mathrm{~m}$ AGL. Moreover, in order to evaluate longrange transport back-trajectories, $120 \mathrm{~h}$ were calculated at 1000, 1500 and $2000 \mathrm{~m}$ AGL for each sample.

\section{Results}

\subsection{Phenolic compounds}

A limited number of papers report PC concentrations in the atmosphere, usually in urban environments and during smoke events. Mean concentrations for SyAH, SyA, VA and VAN were 4.4, 1.8, 1.3 and $1.3 \mathrm{ng} \mathrm{m}^{-3}$ respectively. These results are similar to those reported in the literature (Table 1 and references therein). During the sampling period, the major compounds determined were VA (11\%), VAN (11\%), SyA (16\%), SyAH (38\%) and CAH (10\%). PA, FA, HA and IVA accounted for $14 \%$. PA (2\%) was observed only in fall samples (Table S4).

\subsection{Anhydrosugars, mono- disaccharides and alcohol sugars}

In Belgrade, anhydrosugars in urban aerosols (Table S4) represented a mean percentage of $44 \%$ of the total sugar concentration. From 1 September to 12 December, levoglucosan was at a mean concentration of $424.9 \mathrm{ng} \mathrm{m}^{-3}$ (range 18.8-1791.4 $\mathrm{ng} \mathrm{m}^{-3}$ ). Mannosan and galactosan were at $56.3 \mathrm{ng} \mathrm{m}^{-3}\left(9.6-275.1 \mathrm{ng} \mathrm{m}^{-3}\right)$ and $25.3 \mathrm{ng} \mathrm{m}^{-3}$ (1.9$109.6 \mathrm{ng} \mathrm{m}^{-3}$ ). Levoglucosan represented $84 \%$ of the total anhydrosugar concentration, mannosan and galactosan $11 \%$ and $5 \%$. Mean levels of levoglucosan were comparable to those reported in the literature and ranging, in European cities, between 40 and $2300 \mathrm{ng} \mathrm{m}^{-3}$ (Table 1 and references therein).

The atmospheric concentrations of mono-, disaccharides and alcohol sugars reported in previous studies of urban environments (Table 1 and references therein) are similar to those determined in Belgrade (Table S4). During the sampling period, the mean concentration of glucose was $21.6 \mathrm{ng} \mathrm{m}^{-3}$, that of fructose $83.6 \mathrm{ng} \mathrm{m}^{-3}$, that of galactose $8.6 \mathrm{ng} \mathrm{m}^{-3}$, and that of sucrose $10.8 \mathrm{ng} \mathrm{m}^{-3}$. Among monosaccharides and disaccharides, the prevailing compounds were fructose ( $9 \%$ of total sugar concentration), xylose (8.3\%), arabinose (3.4\%) and glucose (2.3\%). Galactose, mannose and sucrose represented $0.9 \%, 0.7 \%$ and $1.2 \%$, respectively.

Considering polyols (Table S4), the most important compounds were arabitol (6.7\% total mean percentage), mannitol (3.9\%) and glycerol (7.1\%). Xylitol, ribitol, sorbitol + galactiol, erythritol and maltitol represented collectively $2 \%$. In Belgrade the mean concentration of arabitol in fall-winter was of $62.5 \mathrm{ng} \mathrm{m}^{-3}$ and mannitol was $35.9 \mathrm{ng} \mathrm{m}^{-3}$, while 
Table 1

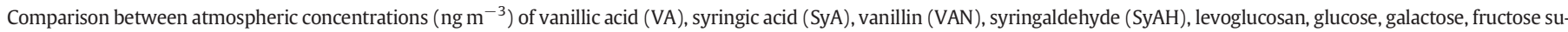
crose, arabitol and mannitol reported in literature and in this study.

\begin{tabular}{|c|c|c|c|c|}
\hline Compound & Site & Season & Concentration $\left(\mathrm{ng} \mathrm{m}^{-3}\right)$ & Ref \\
\hline \multirow[t]{9}{*}{ SуAH } & Dettenhausen (D), urban & Fall-winter & 15.19 & (Bari et al., 2009) \\
\hline & Libby (MT), urban & Winter 2003-2004 & $5.8 \pm 2.7$ & (Ward et al., 2011) \\
\hline & Denver (CO), urban & Yearly & 1.2 & (Simpson et al., 2005) \\
\hline & Seattle (WA), urban & Oct-Jan & $0.09-0.27$ & (Simpson et al., 2005) \\
\hline & Missoula (MT), urban & Smoke events & $0.23-4.03$ & (Ward et al., 2006) \\
\hline & Rodonia (BR), pasture & October & 25.2 & (Graham et al., 2002) \\
\hline & Rodonia (BR), forest & October & 3.1 & (Graham et al., 2002) \\
\hline & Belgrade (SRB) & Fall-winter & 4.4 & This study \\
\hline & Libby (MT), urban & Winter 2003-2004 & $1.4 \pm 0.4$ & (Ward et al., 2011) \\
\hline \multirow[t]{5}{*}{ SyA } & Libby (MT), urban & Winter 2008-2009 & $0.5 \pm 0.5$ & (Ward et al., 2011) \\
\hline & Belgrade (SRB) & Fall-winter & 1.8 & This study \\
\hline & Dettenhausen (D), urban & Fall-winter & 0.33 & (Bari et al., 2009) \\
\hline & Denver (CO), urban & Yearly & 2.44 & (Simpson et al., 2005) \\
\hline & Seattle (WA), urban & Oct-Jan & $0.18-0.29$ & (Simpson et al., 2005) \\
\hline \multirow[t]{4}{*}{ VAN } & Missoula (MT), urban & Smoke events & $2.27-18.9$ & (Ward et al., 2006) \\
\hline & Rodonia (BR), pasture & October & 3.2 & (Graham et al., 2002) \\
\hline & Rodonia (BR), forest & October & 1.2 & (Graham et al., 2002) \\
\hline & Belgrade (SRB), urban & Fall-winter & 1.3 & This study \\
\hline \multirow[t]{9}{*}{ VA } & Libby (MT) & Winter 2003-2004 & $55.5 \pm 12.4$ & (Ward et al., 2011) \\
\hline & Libby (MT) & Winter 2008-2009 & $68.4 \pm 36.5$ & (Ward et al., 2011) \\
\hline & Belgrade (SRB) & Fall-winter & 1.3 & This study \\
\hline & Oporto (P), urban & Winter & 120 & (van Drooge et al., 2014) \\
\hline & Copenhagen (DK), urban & Winter & 40 & (van Drooge et al., 2014) \\
\hline & Amsterdam (NL), urban & Winter & 360 & (van Drooge et al., 2014) \\
\hline & Athens $(G)$ & Winter & 45 & (van Drooge et al., 2014) \\
\hline & Vienna (A), urban & Annual & $120-160$ & (Caseiro et al., 2009) \\
\hline & $\operatorname{Graz}(A)$, urban & Annual & $250-480$ & (Caseiro et al., 2009) \\
\hline \multirow[t]{10}{*}{ Levoglucosan } & Salzburg (A), urban & Annual & $150-220$ & (Caseiro et al., 2009) \\
\hline & Slapanile (CZ), urban & Winter & 572 & (Krumal et al., 2010) \\
\hline & Brno (CZ), urban & Winter & 326 & (Krumal et al., 2010) \\
\hline & Oslo $(\mathrm{N})$, urban & November-December & 166 & (Yttri et al., 2005) \\
\hline & Turin (I), urban & Fall-winter & 680 & (Piazzalunga et al., 2013) \\
\hline & Milan (I), urban & Fall-winter & $390-1210$ & (Piazzalunga et al., 2011) \\
\hline & Florence (I) & Winter & 371 & (Giannoni et al., 2012) \\
\hline & Belgrade (SRB), urban & Fall-winter & 424.9 & This study \\
\hline & Bologna (I) & Fall & 6.9 & (Pietrogrande et al., 2014) \\
\hline & Bologna (I) & Winter & 5.6 & (Pietrogrande et al., 2014) \\
\hline \multirow[t]{5}{*}{ Glucose } & Oslo $(\mathrm{N})$, urban & Fall & 47 & (Yttri et al., 2007) \\
\hline & Elverum $(\mathrm{N})$, suburban & Winter & 22 & (Yttri et al., 2007) \\
\hline & Ghent (B) & Winter & 73 & (Pashynska et al., 2002) \\
\hline & Belgrade (SRB), urban & Fall-winter & 21.6 & This study \\
\hline & Bologna (I) & Fall & 2.8 & (Pietrogrande et al., 2014) \\
\hline \multirow[t]{3}{*}{ Galactose } & Bologna (I) & Winter & 3.0 & (Pietrogrande et al., 2014) \\
\hline & Belgrade (SRB), urban & Fall-winter & 8.6 & This study \\
\hline & Oslo $(\mathrm{N})$, urban & Fall & 42 & (Yttri et al., 2007) \\
\hline \multirow[t]{5}{*}{ Fructose } & Elverum $(\mathrm{N})$, suburban & Winter & 11 & (Yttri et al., 2007) \\
\hline & Ghent (B) & Winter & 37 & (Pashynska et al., 2002) \\
\hline & Belgrade (SRB), urban & Fall-winter & 83.6 & This study \\
\hline & Bologna (I) & Fall & 4.6 & (Pietrogrande et al., 2014) \\
\hline & Bologna (I) & Winter & 3.1 & (Pietrogrande et al., 2014) \\
\hline \multirow[t]{8}{*}{ Sucrose } & Oslo $(\mathrm{N})$, urban & Fall & 150 & (Yttri et al., 2007) \\
\hline & Elverum $(\mathrm{N})$, suburban & Winter & 95 & (Yttri et al., 2007) \\
\hline & Ghent (B) & Winter & 48 & (Pashynska et al., 2002) \\
\hline & Belgrade (SRB), urban & Fall-winter & 10.8 & This study \\
\hline & Oslo $(\mathrm{N})$, urban & Fall & 5.3 & (Yttri et al., 2007) \\
\hline & Elverum $(\mathrm{N})$, suburban & Winter & 5.3 & (Yttri et al., 2007) \\
\hline & Rome (I), urban & Fall & 4.89 & (Di Filippo et al., 2013) \\
\hline & Rome (I), urban & Winter & 20.83 & (Di Filippo et al., 2013) \\
\hline Arabitol & Bologna (I), urban & Fall & 3.4 & (Pietrogrande et al., 2014) \\
\hline & Bologna (I), urban & Winter & 3.83 & (Pietrogrande et al., 2014) \\
\hline & Ghent (B), urban & Winter & 26 & (Pashynska et al., 2002) \\
\hline & Vienna $(A)$, urban & Fall & $7-63$ & (Bauer et al., 2008) \\
\hline & Rehovot (IL), urban & Fall & 18.90 & (Burshtein et al., 2011) \\
\hline & Rehovot (IL), urban & Winter & 8.43 & (Burshtein et al., 2011) \\
\hline & Belgrade (SRB), urban & Fall-winter & 62.5 & This study \\
\hline & Oslo $(\mathrm{N})$, urban & Fall & 8.1 & (Yttri et al., 2007) \\
\hline & Elverum $(\mathrm{N})$, suburban & Winter & 4.2 & (Yttri et al., 2007) \\
\hline & Rome (I), urban & Fall & 22.4 & (Di Filippo et al., 2013) \\
\hline & Rome (I), urban & Winter & 13.47 & (Di Filippo et al., 2013) \\
\hline Mannitol & Ghent (B), urban & Winter & 26 & (Pashynska et al., 2002) \\
\hline & Vienna (A), urban & Fall & $8.9-83.0$ & (Bauer et al., 2008) \\
\hline & Rehovot (IL), urban & Fall & 49.15 & (Burshtein et al., 2011) \\
\hline & Rehovot (IL), urban & Winter & 21.94 & (Burshtein et al., 2011) \\
\hline & Belgrade (SRB), urban & Fall-winter & 35.9 & This study \\
\hline
\end{tabular}




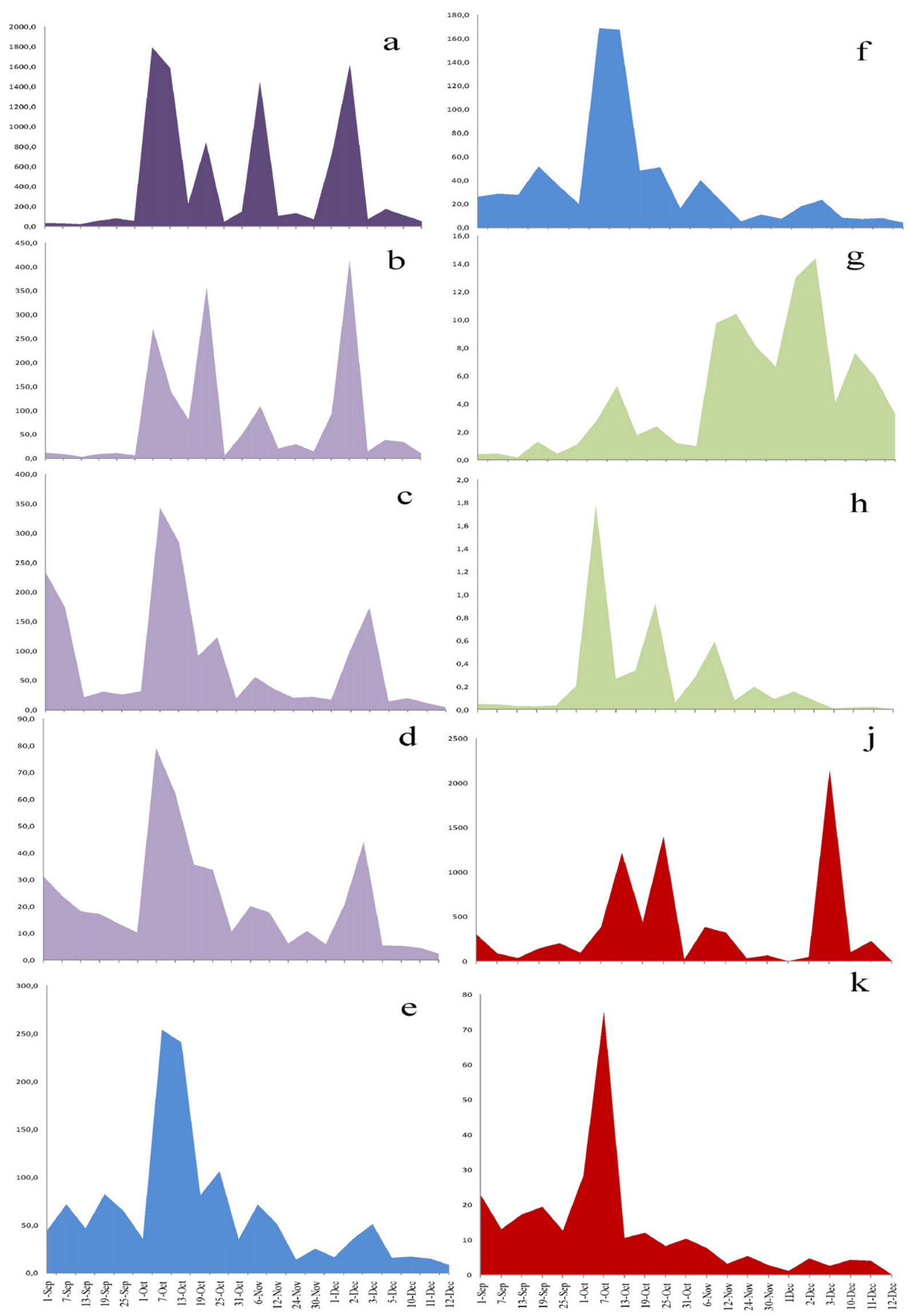

Fig. 1. Temporal trends of levoglucosan (a), xylose (b), fructose (c), glucose (d), arabitol (e), mannitol (f), syringaldehyde (g), p-coumaric acid (h), concentrations (ng $\mathrm{m}^{-3}$ ). Glycine (j) and L-arginine $(\mathrm{k})$, concentrations $\left(\mathrm{pmol} \mathrm{m}^{-3}\right)$, in Belgrade atmosphere. 
Table 2

Mean concentrations determined in September, October, November and December 2008 for PCs, total anhydrosugar concentration and levoglucosan, mannosan, galactosan, monosaccharides, disaccharides, alcohol sugars $\left(\mathrm{ng} \mathrm{m}^{-3}\right)$. In brackets, the percentage of class of sugars with respect to total sugar concentrations.

\begin{tabular}{lllll}
\hline & September & October & November & December \\
\hline PCs & 1.9 & 10.1 & 17.6 & 17.7 \\
Sugars total & 355.6 & 1656.5 & 772.1 & 769.2 \\
Anhydrosugars & $65.1(18.3 \%)$ & $875.1(52.8 \%)$ & $521.0(67.5)$ & $457.5(62.5)$ \\
Levoglucosan & 42.0 & 753.7 & 454.9 & 399.3 \\
Mannosan & 18.1 & 83.7 & 41.7 & 68.5 \\
Galactosan & 5.4 & 37.7 & 24.4 & 29.7 \\
Monosaccharides & $140.3(39.5 \%)$ & $418.2(25.2 \%)$ & $123.4(16.0 \%)$ & $186.2(23.4 \%)$ \\
Disaccharides & $12.5(3.5 \%)$ & $21.4(1.3 \%)$ & $4.6(0.6 \%)$ & $5.8(0.7 \%)$ \\
Alcohol sugars & $140.2(39.4 \%)$ & $345.2(26.8 \%)$ & $123.0(15.9 \%)$ & $106.7(13.4 \%)$ \\
\hline
\end{tabular}

the literature data range between 3.4 and $63 \mathrm{ng} \mathrm{m}^{-3}$ and 4.2 and $83 \mathrm{ng} \mathrm{m}^{-3}$ (Table 1 and references therein).

\subsection{D-L amino acids}

In the particulate matter sampled in Belgrade, the total mean concentration of free amino acids (FAAs) was $564.2 \mathrm{pmol} \mathrm{m}^{-3}$ $\left(69.4 \mathrm{ng} \mathrm{m}^{-3}\right)$ for L-AAs and $35.7 \mathrm{pmol} \mathrm{m}^{-3}\left(3.5 \mathrm{ng} \mathrm{m}^{-3}\right)$ for D-AAs, while the total mean concentration of $(\mathrm{L}+\mathrm{D})$-AAs was $599.9 \mathrm{pmol} \mathrm{m}^{-3}\left(72.9 \mathrm{ng} \mathrm{m}^{-3}\right)$. In urban environments, the literature reports atmospheric concentrations of L-FAAs ranging between 334 and 2470 pmol m$~^{-3}$ (Barbaro et al., 2011; Di Filippo et al., 2014; Yang et al., 2005; Zhang and Anastasio, 2003). In marine and marine remote aerosols, lower levels ranging from 1.5 to $648 \mathrm{pmol} \mathrm{m}^{-3}$ were observed (Barbaro et al., 2015; Mace et al., 2003b; Mace et al., 2003c; Matsumoto and Uematsu, 2005; Wedyan and Preston, 2008). At a Polar coastal site in the Arctic (Ny Alesund, Svalbard Islands) (Scalabrin et al., 2012), during the summer, FAAs ranged from 0.59 to $4.7 \mathrm{pmol} \mathrm{m}^{-3}$. On a coastal site in Antarctica (Mario Zucchelli Station, Victoria Land), the mean level was $11 \mathrm{pmol} \mathrm{m}^{-3}$. On the Antarctic plateau, the mean levels were $0.8 \mathrm{pmol} \mathrm{m}^{-3}$ in 2011-2012 and $0.7 \mathrm{pmol} \mathrm{m}^{-3}$ in 2012-2013 (Barbaro et al., 2015).

In Belgrade aerosols, between September and December (Table S4), the most important AA was Gly, which represented $46.7 \%$ of total the FAAs, followed by L-Ala (8.6\%), L-Glu (7.1\%), L-Arg 5.9\%, L-Val (5.5\%) and L-Asp (3\%). All D-AAs represented $<1 \%$ of the total. These results are in good agreement with the observations of other authors, according to whom Gly is the most abundant AA followed by lower percentages of L-Ser, L-Ala, L-Asp, L-Arg, and L-Glu in both urban (Barbaro et al., 2011; Di Filippo et al., 2014; Zhang and Anastasio, 2003) and marine aerosols (Barbaro et al., 2015; Mace et al., 2003c; Mandalakis et al., 2011; Matsumoto and Uematsu, 2005; Scalabrin et al., 2012).

\section{Discussion}

The temporal trends studied in Belgrade's atmosphere (Table S4) are characterized as follows: higher concentrations are registered for the samples of 7, 13, 25 October, 12 November and 3 December for anhydrosugars (Figs. 1 and S3), mono- and disaccharides, (Fig. S4), alcohol sugars (Figs. 1, S5 and S6) and AAs (Figs. 1,S7_S13) in comparison to the levels registered in September, and to the other samples collected in November and December.

Relevant concentrations of PCs were observed in October, although the highest ones were observed in December. PC concentrations increased from fall to winter. (Table 2, S4, Figs. 1, S14).

Seasonal trends for anhydrosugars (Fig. S3, Table 2) show lower values in September. In October, a sudden increase in concentrations of biomass combustion tracers levoglucosan, mannosan and galactosan was observed due to open fire events. The overlap of HYSPLIT (Draxler

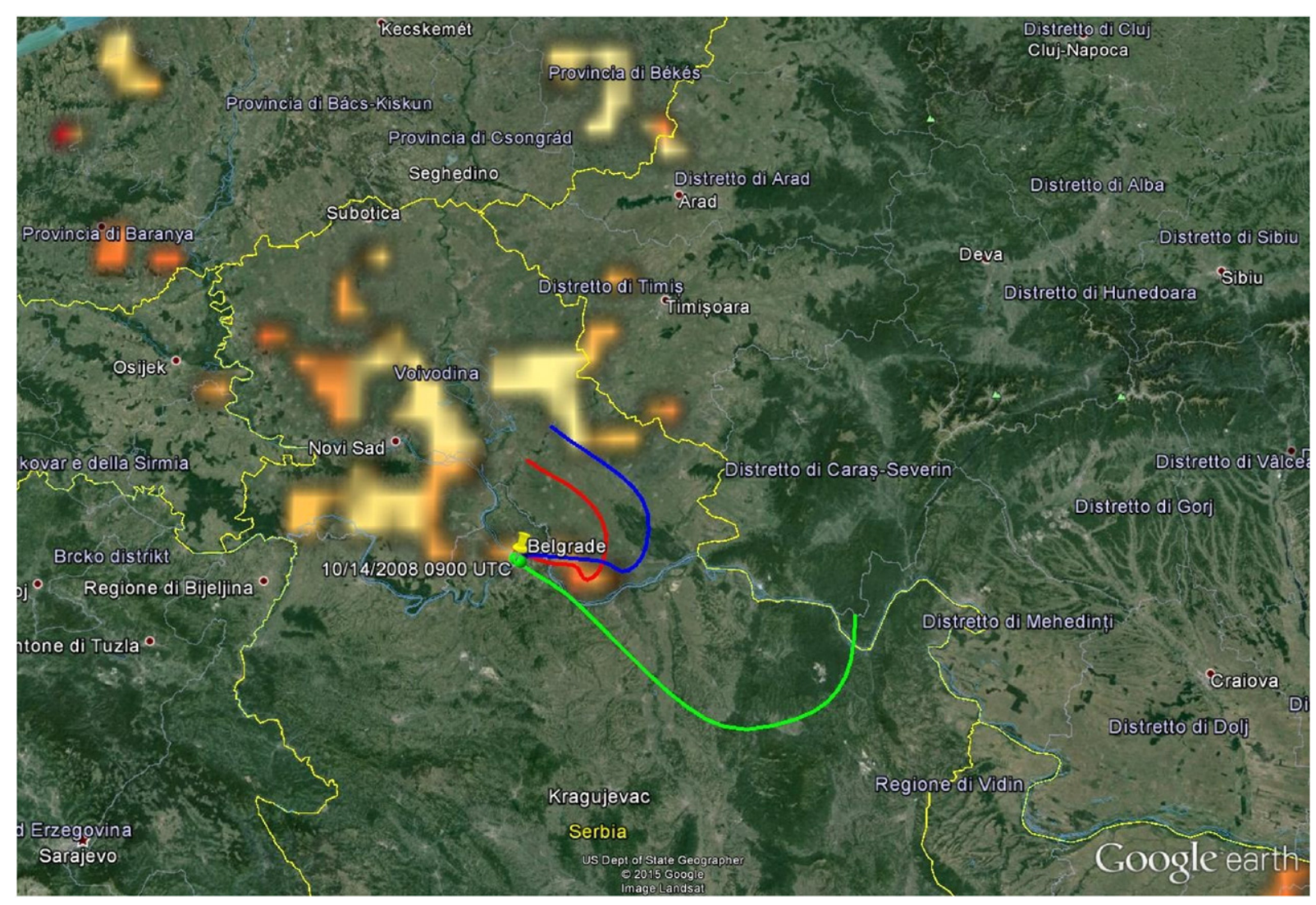

Fig. 2. MODIS satellite image (NEO Active Fires) of 13 October 2008 and HYSPLIT $24 \mathrm{~h}$ back trajectories $200 \mathrm{~m}$ (red), $500 \mathrm{~m}$ (blue), $1000 \mathrm{~m}$ (green). 


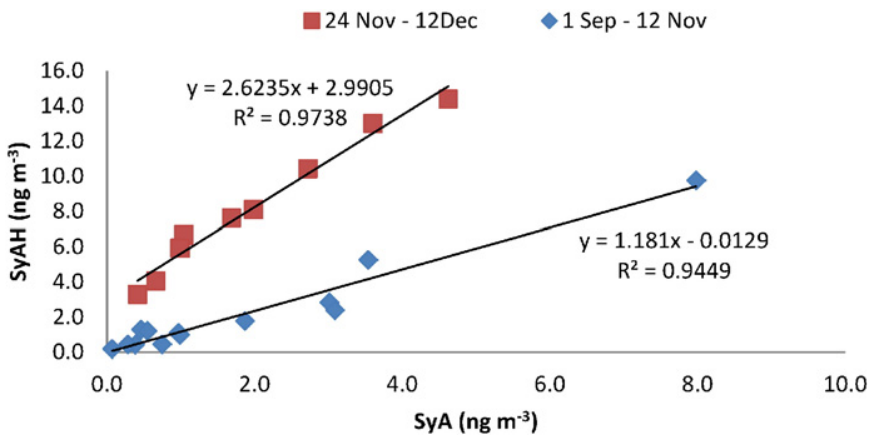

Fig. 3. Plot reporting SyA versus SyAH. Blue diamonds represented fall samples while red squares winter samples.

and Rolph, 2012) $24 \mathrm{~h}$ back trajectories and Active Fires from NEO (NASA) shows that the air masses that reached Belgrade on 7, 13, 19, 25 October had passed above fire areas (see Figs. 2 and S15). We considered the possibility these high concentrations could be from long-range transport. $120 \mathrm{~h}$ back-trajectories did not show intense fires along the air masses journey (Figs. S16-S18) except for fires in the North of Serbia, demonstrating that these high levels were caused by local events. These observations agree with Vojkan \& Bojana (Vojkan and Bojana, 2013), who regularly observed open fire phenomena in Serbia in the month of October every year from 2000 to 2013, due to the burning of agricultural waste.

In November and December, similar mean concentrations of levoglucosan, mannosan and galactosan were registered due to the exploitation of wood for energy production in households (Glavonjic, 2011), industry, and commercial and public facilities (Glavonjic and Oblak, 2012).

These events also affected the atmospheric concentrations of sugars (Figs. S4-S6). In the September samples (Table 2), collected at the end of the growing season, the mean total sugar concentration was $355.6 \mathrm{ng} \mathrm{m}^{-3}$; in October, due to the increase of agricultural waste combustion, there was a general increase in atmospheric sugar concentrations to a total mean of $1656.5 \mathrm{ng} \mathrm{m}^{-3}$, consisting principally of anhydrosugars. Because biomass burning is a source of sugars (Medeiros et al., 2006), monosaccharides, disaccharides and alcohol sugars increased as well. In November and December, the sugar levels decreased, but remained higher than in September. The same occurred for monosaccharide disaccharide and alcohol sugar levels. However, due to residential wood burning (Glavonjic, 2011), anhydrosugars contributed to most of the total sugar concentrations detected in the Belgrade aerosols in November at a percentage of $67.5 \%$ and December of $62.5 \%$ (Table 2 ).

Among the most abundant sugars detected, the monthly mean percentages of glucose, fructose and sucrose decreased progressively form September to December (Tables 2, S4). This data is in agreement with Medeiros et al. (Medeiros et al., 2006), who observed higher concentrations in the spring and lower ones in the summer, as the growing season progresses. Sucrose is relevant only in the spring as it is particularly important for the development of flowers buds (Medeiros et al., 2006). Arabinose and galactose are produced from the combustion of leaves and needles, which are rich in pectin (Medeiros et al., 2006). The highest concentrations of these compounds were observed in the samples collected in October (Table S4).

From September to December, the mean concentrations of arabitol and mannitol decreased from $61.5 \mathrm{ng} \mathrm{m}^{-3}$ to $22.5 \mathrm{ng} \mathrm{m}^{-3}$ and from $33.6 \mathrm{ng} \mathrm{m}^{-3}$ to $10.6 \mathrm{ng} \mathrm{m}^{-3}$, respectively. The highest concentrations were registered in October at $124.9 \mathrm{ng} \mathrm{m}^{-3}$ and $78.4 \mathrm{ng} \mathrm{m}^{-3}$, respectively. These values may be due to high fungal growth and open fire events in this season.

Different kinds of biomass burning events, such as wildfire, burning of agricultural waste and the exploitation of wood as an energetic source, can contribute to the total aerosol load in the atmosphere. A first indication of different biomass burning sources can derive from the observation of the temporal trends of PCs (Figs. 1 and S14). The PC trend shows a sudden increase of atmospheric concentrations of SyAH, CAH and SyA on 12 November. It also shows a marked difference between the samples collected from September to 12 November and those collected from 24 November to 12 December. This is highlighted in Fig. 3, where SyA was plotted against SyAH, showing a good separation between fall and winter concentrations.

In order to better understand the different kinds of combustion sources during the sampling, we studied the sampling period while considering the monthly mean percentage of PCs and the L/M ratio.

Among the PCs, we considered V (sum of VA and VAN), S (SyA + SyAH) and PA as indicators of the type of wood combusted, as these compounds are respectively present in softwood, hardwood and grasses (Kuo et al., 2011; Opsahl and Benner, 1998). In September and October, the percentages of $\mathrm{V}(41 \%$ and $36 \%$ ) and S (56\% and 58\%) were similar, while PA increased from $3 \%$ to $6 \%$, due to a surge of grass fires. In November, PA contributed 3\%, indicating residual open fires; $\mathrm{V}$ decreased to $29 \%$; and S increased to $68 \%$, probably due to the start of domestic heating that uses firewood as fuel. In December, we observed a further decrease in $\mathrm{V}(23.5 \%)$ and an increase in S to 76\%, indicating the use of hardwood (Oros and Simoneit, 2001b) in house heating.

In previous studies, $\mathrm{L} / \mathrm{M}$ ratios were used as indicators of the kind of biomass burned, although these ratios are quite variable (Fabbri et al., 2009). In the smoke $\mathrm{L} / \mathrm{M}$ values of 2.5 were observed for briquettes, of 3.6-3.9 for softwood and of 14.4-14.8 for hardwood (Schmidl et al., 2008b). Regarding grass combustion, L/M ratios ranged between 2 and 33 (Oros et al., 2006); for leaves combustion, the mean value was 5.5 (Schmidl et al., 2008a); and for crop combustion, the mean values were 32.6 (12.7-55.7) (Sang et al., 2013). In atmospheric aerosols, L/M mean values ranged between 3.5 and 75 (Fabbri et al., 2009). In Belgrade aerosols, the mean $\mathrm{L} / \mathrm{M}$ ratio was 2.3 (range 1.5-3.0) in September. In October, due to a bonfire increase, the ratios increased to 7.6 (range 2.5-16.7). In November, residual open fires and domestic heating resulted in a mean value of 8.0 (range 3.5-18.6). In December, a value of 5.0 (3.4-8.2) was observed.

In this study $\mathrm{V}, \mathrm{S}$ and PA proved useful to indicate the type of wood fuel involved in the combustion, while the increase of L/M ratio distinguished the period in which the open fires occurred.

Table 3

$\mathrm{D} / \mathrm{L}$ AA ratios reported in literature and determined in Belgrade aerosols.

\begin{tabular}{|c|c|c|c|c|c|c|c|c|}
\hline & Ala & Ser & Glu & Asp & Thr & Phe & Sampling site & Reference \\
\hline Aerosol & 0.35 & 0.11 & & & & & Atlantic Ocean & Wedyan and Preston, 2008 \\
\hline Aerosol & $0.06-0.16$ & $0.02-0.13$ & $0.06-0.07$ & $0.09-0.15$ & & & Mediterranean Sea & Kuznetsova et al., 2005 \\
\hline Aerosol & $0.04-0.07$ & $0.02-0.05$ & $0.01-0.20$ & $0.03-0.12$ & & & Long Island Sound & Kuznetsova et al., 2005 \\
\hline Rainwater & 0.61 & 0.21 & 0.26 & 0.34 & & & Seoul (urban) & Yan et al., 2015 \\
\hline Rainwater & 0.31 & 0.09 & 0.11 & 0.18 & & & Uljin (coastal rural / marine) & Yan et al., 2015 \\
\hline Aerosol & 0.38 & 0.18 & & 0.08 & 0,72 & 0.42 & Belgrade Mean sampling campaign & this work \\
\hline Aerosol & 0.88 & & & 0.23 & 1.42 & 1.57 & Belgrade Open fire samples & this work \\
\hline Aerosol & 0.23 & & & 0.03 & 0.49 & 0.07 & Belgrade No open fire samples & this work \\
\hline
\end{tabular}


The impact of biomass burning on aerosol concentrations in the atmosphere of Belgrade can be evaluated using the glucose/levoglucosan (Samburova et al., 2013 ) ratio, where a value of $\approx 4.5$ indicates smokefree samples, and 0.9 indicates samples affected by smoke. This ratio was calculated by considering that the mean concentrations of glucose and levoglucosan reported for atmospheric urban aerosols in fall-winter ranged between 0.02 and 0.2 (Pashynska et al., 2002; Pietrogrande et al., 2014; Yttri et al., 2007). Throughout the sampling campaign in Belgrade, a comparable value of 0.02 (range 0.98-0.01) was calculated.

The temporal trends of AAs (Figs. 1, S7-S13) show higher levels in the first part of September. An abrupt increase in October and early November occurred in coincidence with bonfires (7, 13, 19, 25 October, 12 November). A decrease was observed in November and December, except for Gly, which showed high levels also on 3 December (Fig. 1). The literature reports a possible connection between high FAA concentrations and biomass burning (Mace et al., 2003a; Samy et al., 2013) and our data seem to support the same connection for open fire.

Very few studies report levels of D-AA in atmospheric aerosols. Wedyan \& Preston (Wedyan and Preston, 2008) observed a strong enantiomeric excess of L-AAs in marine aerosols, indicating a relevant proportion of fresh rather than microbially degraded material. In addition, they reported the presence of D-AAs, among which D-Ala was the most abundant AA. The mean D/L ratio for hydrolyzable AAs was 0.35 for Ala and 0.11 for Ser. Kuznetsova et al. (Kuznetsova et al., 2005) studied the presence of total AAs in the Mediterranean Sea and in Long Island Sound. They reported the presence of D-AAs, with a D/L ratio for Asp, Glu, Ser, Ala generally below 0.2 (see Table 3). Yan et al. (Yan et al., 2015) discussed the presence of D-AAs in rainwater samples collected in Seoul (urban site) and Uljin (coastal rural site with marine input). The comparison of mean D/L ratios for Asp, Glu, Ser, Ala (Table 3 ) between the urban and rural sites showed higher values for Seoul than for Uljin, suggesting that the former site presents a higher level of microbial degradation and that $\mathrm{D} / \mathrm{L}$ ratios can be used as indicators of such degradation.

In Belgrade, we detected D-Ala in all the samples (Fig. S11) from September to November and in a few samples in December. D-Asp, DThr, D-Phe and D-Ser were observed sporadically, except for samples from 7, 13, 19, 25 October and 12 November, which were affected from open fires (Table S4). The mean D/L ratios from September to December for Asp, Thr, Phe, Ser and Ala were similar to those reported in the literature (Table 3). Interestingly, the Student $t$-test proved that the mean values of the $\mathrm{D} / \mathrm{L}$ ratio for samples affected by open fire ( 7 , $13,19,25$ October and 12 November) were significantly higher than the mean values calculated for the samples unaffected by fire: for Asp $\mathrm{D} / \mathrm{L}$, the mean value for samples affected by fire was 0.23 , and for unaffected samples $0.03, p=0.00083$, Thr 1.42, $0.49, p=0.028$, Phe 1.57, $0.07, p=0.0027$ and Ala $0.88,0.23, p=0.00068$. These higher values observed in samples affected by fire can be explained by the atmospheric input during combustion-related soil re-suspension. Soils include bacterial material (Amelung et al., 2006; Simoneit et al., 2004; Vranova et al., 2012) and degraded material in vegetal waste.

\subsection{Primary sources of particulate matter in the Belgrade atmosphere}

In order to identify the different sources contributing to the total composition of the samples, different statistical approaches were applied to these data. In the matrix of data obtained from Table S4, the compounds that were mainly below detection limit (BDL) were excluded from statistical analysis. In the samples where variables BLD were $<50 \%$, the value corresponding to half the limit of detection was substituted to BDL. The auto-scaled data matrix was used in statistical analysis.

Hierarchical Cluster Analysis (CA) performed using Statistica 8.0 (Ward's method, Squared Euclidean Distance) produced a tree diagram whose variables were divided in two macro-clusters A and B. In macrocluster A (Fig. 4) the compounds related to biomass burning: phenolic

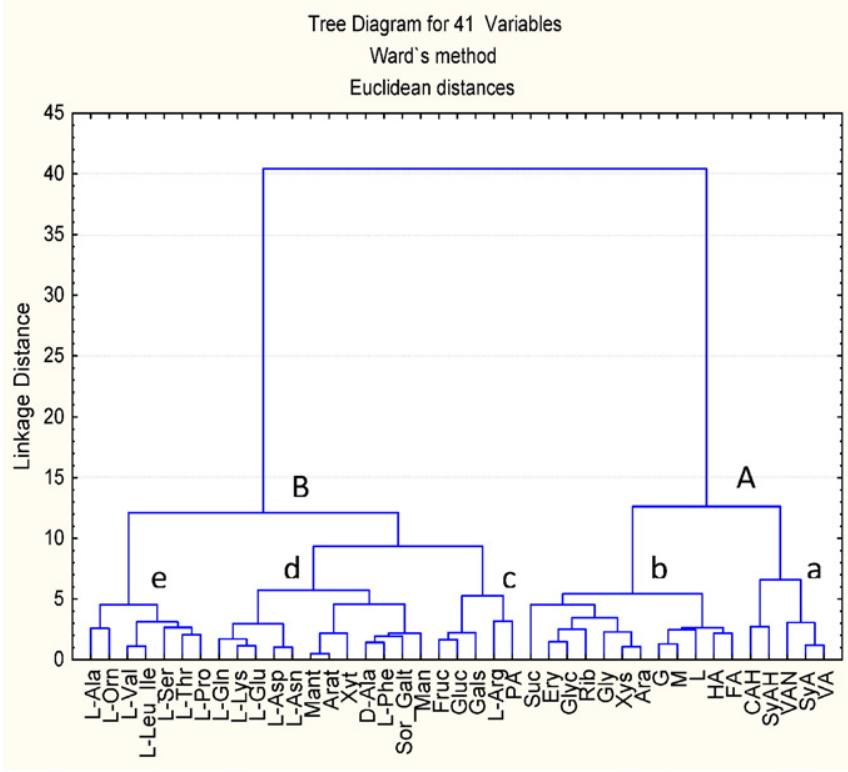

Fig. 4. Result of Hierarchical Cluster Analysis.

compounds (lignin combustion) (cluster (a)). In the cluster (b), two sub-clusters are present the first contains levoglucosan, mannosan and galactosan (cellulose and hemicellulose combustion) HA and FA,

Table 4

Factor loadings in factor analysis.

\begin{tabular}{|c|c|c|c|c|c|}
\hline & Factor 1 & Factor 2 & Factor 3 & Factor 4 & Factor 5 \\
\hline VA & -0.172 & 0.585 & 0.142 & 0.612 & 0.136 \\
\hline VAN & -0.128 & 0.301 & 0.525 & 0.697 & 0.068 \\
\hline SyA & -0.189 & 0.497 & 0.160 & 0.682 & 0.146 \\
\hline SyAH & -0.300 & 0.332 & -0.140 & 0.833 & -0.111 \\
\hline PA & 0.234 & 0.332 & 0.846 & 0.072 & 0.145 \\
\hline FA & -0.053 & 0.822 & 0.039 & 0.484 & -0.015 \\
\hline $\mathrm{HA}$ & -0.148 & 0.860 & 0.041 & 0.394 & 0.079 \\
\hline $\mathrm{CAH}$ & -0.187 & 0.157 & -0.164 & 0.716 & -0.234 \\
\hline $\mathrm{L}$ & 0.102 & 0.675 & 0.364 & 0.467 & 0.385 \\
\hline M & -0.016 & 0.769 & -0.027 & 0.352 & 0.386 \\
\hline G & -0.045 & 0.856 & 0.073 & 0.386 & 0.302 \\
\hline Ara & 0.090 & 0.933 & 0.238 & 0.113 & 0.191 \\
\hline Man & 0.106 & 0.502 & -0.017 & -0.094 & 0.835 \\
\hline Xys & 0.043 & 0.935 & 0.295 & 0.143 & -0.038 \\
\hline Gals & 0.354 & 0.647 & 0.521 & 0.081 & 0.228 \\
\hline Gluc & 0.481 & 0.550 & 0.429 & 0.044 & 0.476 \\
\hline Fruc & 0.726 & 0.451 & 0.225 & 0.108 & 0.412 \\
\hline Suc & 0.202 & 0.788 & -0.305 & -0.294 & 0.141 \\
\hline Xyt & 0.444 & 0.259 & 0.333 & -0.100 & 0.704 \\
\hline Arat & 0.336 & 0.349 & 0.499 & -0.111 & 0.698 \\
\hline Rib & 0.189 & 0.687 & 0.325 & 0.044 & 0.485 \\
\hline Sor_Galt & 0.357 & 0.343 & 0.026 & 0.036 & 0.833 \\
\hline Mant & 0.323 & 0.286 & 0.484 & -0.079 & 0.742 \\
\hline Glyc & -0.020 & 0.899 & 0.103 & 0.096 & 0.385 \\
\hline Ery & 0.133 & 0.788 & 0.289 & 0.079 & 0.504 \\
\hline L-Asn & 0.666 & 0.100 & -0.072 & -0.050 & 0.727 \\
\hline L-Asp & 0.582 & 0.181 & -0.032 & -0.052 & 0.759 \\
\hline L-Glu & 0.644 & 0.096 & 0.168 & -0.085 & 0.723 \\
\hline L-Lys & 0.782 & 0.026 & 0.253 & -0.059 & 0.548 \\
\hline L-Pro & 0.947 & -0.152 & -0.113 & -0.085 & 0.099 \\
\hline L-Thr & 0.889 & -0.011 & 0.116 & -0.045 & 0.391 \\
\hline L-Arg & 0.524 & -0.088 & 0.764 & -0.100 & 0.141 \\
\hline L-Leu_Ile & 0.875 & 0.006 & 0.105 & -0.262 & 0.245 \\
\hline Gly & 0.008 & 0.961 & -0.111 & -0.008 & 0.127 \\
\hline L-Orn & 0.678 & 0.045 & 0.306 & -0.316 & 0.368 \\
\hline L-Phe & 0.464 & 0.154 & 0.065 & 0.072 & 0.842 \\
\hline L-Ser & 0.833 & 0.045 & 0.287 & -0.252 & 0.142 \\
\hline L-Ala & 0.533 & 0.225 & 0.140 & -0.521 & 0.374 \\
\hline L-Gln & 0.624 & 0.024 & 0.373 & -0.235 & 0.589 \\
\hline L-Val & 0.845 & -0.050 & 0.145 & -0.225 & 0.342 \\
\hline D-Ala & 0.374 & 0.395 & 0.094 & 0.037 & 0.804 \\
\hline
\end{tabular}



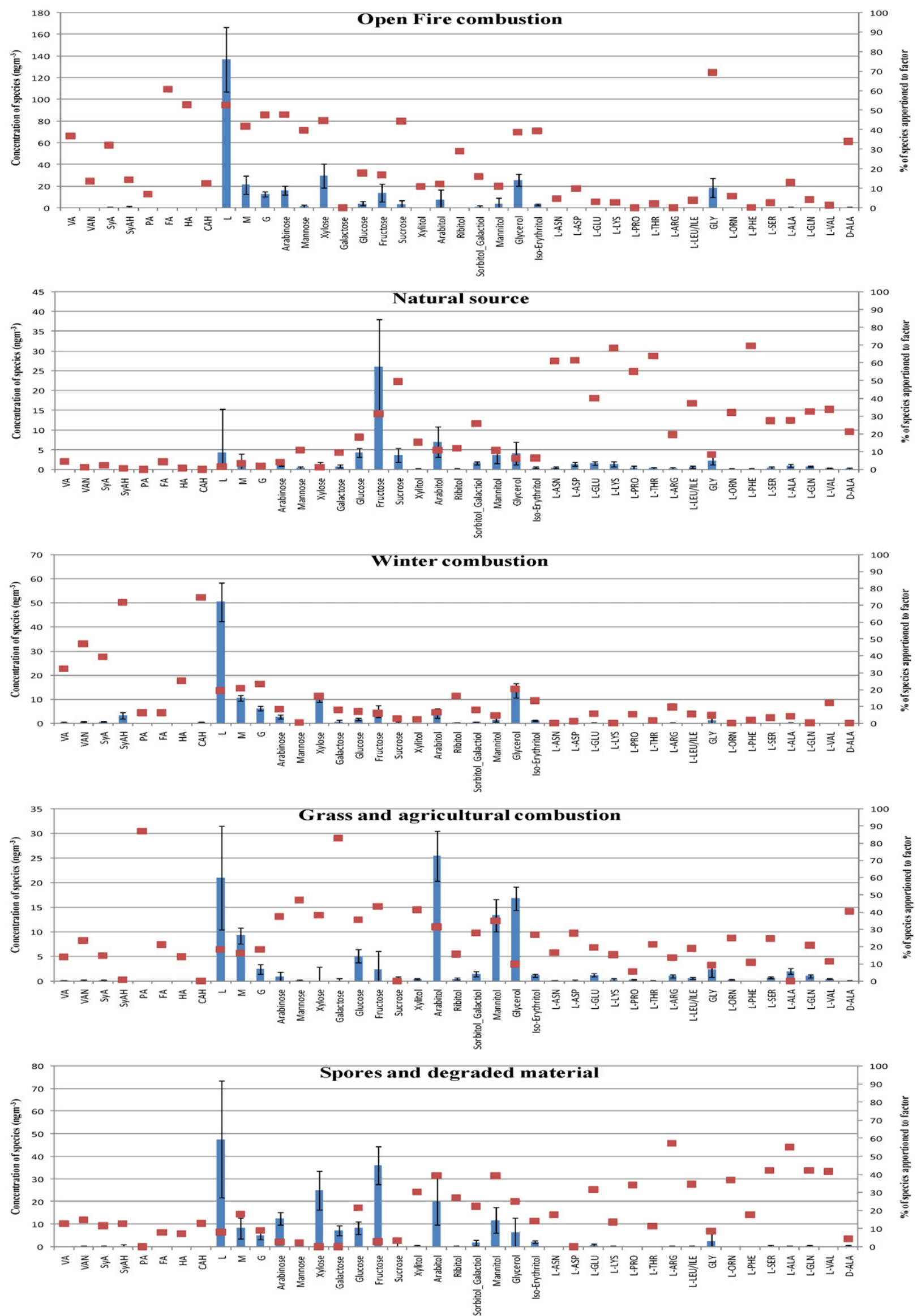

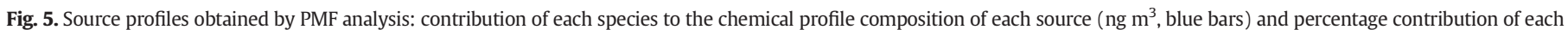
source to the concentration of each species (\%, red squares). 
while the second includes sugars and sugar alcohol from vegetal combustion. The second macro-cluster (B) is separated in two clusters, the first cluster (c) contain sugars such as glucose, fructose and galactose (vegetal material), L-Arg (an AA linked to urea cycle (Zhang and Anastasio, 2003)) and PA (grass combustion (Oros et al., 2006)). The second cluster (d) consists of mannitol and arabitol (fungal spore (Bauer et al., 2008)) and D-Ala (from bacteria). The second macrocluster contains also L-AAs as markers of biological fresh material (e).

PCA and factor analysis (FCA) aim to reduce the dimensionality of a set of data using different approaches (Joliffe, 2002). PCA and FCA provide different insights and can be informative when jointly applied to the same data set. PCA and FcA were performed using Statistica 8.0 and the five factors considered explained $91.4 \%$ of the cumulative variance. PCA showed high negative factor loadings for sugars and amino acids in PC1 (attributable to a "natural source"), while PC2 presented high positive values for anhydrosugars and phenolic compounds indicating a generic "biomass burning" source for this component (data not shown).

For FcA, varimax rotation was applied. High values of factor loadings (Table 4) were shown in Factor 1 for AAs ("natural" factor); in Factor 2 factor loadings were high for compounds from biomass combustion such as anhydrosugars, PCs, sugars as glycerol and erythritol and Gly (open fire combustion factor). In Factor 3 high factor loadings were for PA and L-Arg we can therefore infer that this Factor is linked to the combustion of grass and biological material (grass combustion). Factor 4 presents high loading values for PCs such as VA, VAN, SyAH, SyA and $\mathrm{CAH}$, indicating a different kind of combustion typical of the winter period (winter combustion factor); Factor 5 presents high values of compounds connected to degraded organic material affected by fungi (mannitol and arabitol, sugar alcohol), bacteria (D-Ala), and other LAAs, indicating the combustion of degraded material.

In order to obtain more detailed information from our samples, we tried to apply a Positive Matrix Factorization (PMF) (Paatero, 1997; Paatero and Tapper, 1994), although our data set consisted of only 19 samples. This statistical technique has been widely applied in literature with the aim to assess the sources that contribute to atmospheric aerosol composition. Handling PMF data required discriminating between "bad", "weak" and "strong" variables according to signal-to-noise ratio criteria (Paatero and Hopke, 2003). We set all the variables "strong". The choice of the solution was based on the results obtained by the model from 3 to 10 factors. The resulting parameters obtained from the scaled residual matrix, IM (the maximum individual column mean), and IS (the maximum individual column standard deviation), together with $Q$ values, were examined to identify the most reasonable solution (Lee et al., 1999; Viana et al., 2008). For Q values, the solution to the system was the point where the slope of the curve showed a marked change. When the number of factors increased to a critical value, the IM and IS parameters experienced a very marked drop. In the present work, the $Q$ IM and IS values showed a reasonable solution in correspondence with 5 factors. Considering the total concentration of all the compounds that we determined and used in the PMF elaboration, the linear regression between the real value determined experimentally and those calculated from the model showed a $\mathrm{R}^{2}$ of 0.9668 .

The results obtained by PMF are similar to those obtained by FcA. In PMF factor profiles (Fig. 5), high percentages of levoglucosan, mannosan and galactosan are reported for factors F1, F3, and F4, indicating three factors connected to different kinds of biomass burning: PMF F1 presented the highest percentages of levoglucosan, mannosan, galactosan, VA, FA, HA, glycerol, erythritol and Gly (this last compound is related to long-range transport), good percentages of methoxy phenols (SyA, $\mathrm{SyAH}$ ), and a relevant presence of D-Ala. This factor is correlated to Factor 2 in FcA (Pearson $r=0.91$ ) with higher contribution in October individuating an open fire source. PMF F2 showed high percentages of sucrose and L-AAs, showing a correlation $(r=0.71)$ to Factor 1 in FcA. PMF F2 can be related to a "natural" source. PMF F3 showed the highest contribution of VAN, SyA, SyAH, CAH and a good percentage of levoglucosan, mannosan and galactosan. This factor is correlated to Factor 4 in FcA ( $r=0.85)$, with higher contribution in winter samples (winter combustion) when firewood is burned for house heating. In PMF F4 the most relevant feature is the highest percentage of PA attributable to grass combustion; galactose can be attributed to the combustion of pectin present in leaves and needles (Medeiros et al., 2006); sugars (glucose, fructose and sucrose) are connected to vegetation; mannose to soil resuspension (Simoneit et al., 2004) and D-Ala (bacteria). Levoglucosan, mannosan and galactosan (tracers of biomass burning) are present in PMF F4 in good percentages; so are mannitol and arabitol, which are linked to vegetation and mature leaves (Pashynska et al., 2002) as well as to fungi spores. We can consider PMF F4 to be primarily associated to the combustion of grass and agricultural waste. This factor contributes remarkably to the sample collected on 7 October (Table 5). PMF F5 is characterized by high percentages of mannitol and arabitol markers of fungi spore; L-AAs, especially L-Orn and L-Arg, are linked to animal origins such as livestock (Zhang and Anastasio, 2003); the good percentage of alcohol sugars indicates a relation to fungal spores and degraded material.

PMF contributions showed high values of F2 (natural factor) for the samples collected in the summer on 1 and 7 September (Table 5). The sample from 7 October shows a high contribution of F4 (grass combustion). The 13 October sample presented high values for F1 (open combustion) with a relevant contribution of F2 (natural). The different contributions to these two samples are drawn from temporal trends (Figs. S1-S13) and they are confirmed by statistical elaboration. An additional explanation comes from HYSPLIT back-trajectories, which demonstrate the different geographical origins of the air masses. On 7 October, the air masses came from Vojvodina, while on the 13 October they came from the South and South-East (Figs. S15 and 2).

For the samples collected on 19 and 25 October, the contribution came from open-combustion and grass-combustion factors (F1 and F4); on 19 October, the contribution came also from degraded material. The 12 November sample was affected mainly by open fire combustion (F1) and winter combustion (F3). In general, all the samples collected from 12 November to December indicated a relevant contribution of winter combustion (F3). The sample collected on 3 December, in particular, presented a relevant contribution also from open combustion (F1).

\section{Conclusions}

In this work we applied two new methods. A HPAEC-(-)-APCIOrbitrapMS for the determination of levoglucosan, mannosan and galactosan and a HPLC-(-)-ESI-OrbitrapMS for PCs in particulate matter. We also applied two additional, previously validated methods for the determination of sugars, alcohol sugars and D and L-AAs using these compounds as tracers of primary sources in Belgrade aerosols collected from September to December 2008 during the seasonal transition.

This study contributes to improving our currently scarce knowledge about the atmospheric concentration of water-soluble organic compounds in the Belgrade area.

The sampling campaign was characterized by the presence of different kinds of biomass burning sources. Particularly high values of biomarkers were observed in October in conjunction with the frequent wildfire and bonfire events that affected the Belgrade area. The temporal trends of PCs, and in particular the high atmospheric concentration of SyAH and CAH in November-December, indicated a different biomass combustion source, probably linked to domestic heating.

The indications from temporal trends were confirmed by studying the relative percentage abundance of vanillic $\mathrm{V}(\mathrm{VA}+\mathrm{VAN})$ and syringic S (SyA + SyAH) compounds and of p-coumaric acid (PA) in September, October, November and December. These parameters identified the presence of grass combustion in the fall and the employment of hardwood in domestic heating in December. The L/M ratios calculated during the sampling period highlight open fires in October and 
Factor contribution in PMF analysis $\left(\mathrm{ng} \mathrm{m}^{-3}\right)$.

\begin{tabular}{|c|c|c|c|c|c|}
\hline & $\begin{array}{l}\text { F1 Open fire } \\
\text { combustion }\end{array}$ & $\begin{array}{l}\text { F2 Natural } \\
\text { contribution }\end{array}$ & $\begin{array}{l}\text { F3 Winter } \\
\text { combustion }\end{array}$ & $\begin{array}{l}\text { F4 Grass and agricultural } \\
\text { combustion }\end{array}$ & $\begin{array}{l}\text { F5 Fungi spores and } \\
\text { degraded material }\end{array}$ \\
\hline 1- Sep & 0 & 514.3 & 17.4 & 47.5 & 0 \\
\hline 7-Sep & 0 & 269.2 & 0 & 86.1 & 136.2 \\
\hline 13-Sep & 0 & 52.2 & 0 & 61.6 & 151.7 \\
\hline 19-Sep & 0 & 0 & 0 & 108.4 & 320.4 \\
\hline 25-Sep & 71.7 & 18.7 & 0 & 63.4 & 203.0 \\
\hline 1-Oct & 55.5 & 74.8 & 15.4 & 0 & 141.7 \\
\hline 7- Oct & 0 & 0 & 19.0 & 1756.3 & 461.6 \\
\hline 13- Oct & 1399.4 & 426.8 & 26.8 & 374.8 & 5.4 \\
\hline 19- Oct & 346.2 & 0 & 0 & 387.3 & 189.9 \\
\hline 25- Oct & 1280.9 & 0 & 0 & 506.2 & 103.7 \\
\hline 31- Oct & 0 & 20,1 & 28,5 & 46,28 & 132,4 \\
\hline 6- Nov & 228.0 & 37.3 & 0 & 227.0 & 157.3 \\
\hline 12- Nov & 629.9 & 4.5 & 253.7 & 0 & 106.7 \\
\hline 24- Nov & 0 & 27.1 & 301.9 & 0 & 5.5 \\
\hline 30- Nov & 20.9 & 0 & 232.2 & 90.1 & 35.8 \\
\hline 2- Dec & 0 & 0 & 571.4 & 230.0 & 0 \\
\hline 3- Dec & 1969.6 & 0 & 368.5 & 0 & 0 \\
\hline 10- Dec & 61.8 & 4.6 & 318.4 & 9.5 & 6.9 \\
\hline 11- Dec & 108.3 & 14.9 & 178.6 & 0 & 35.8 \\
\hline
\end{tabular}

November. The simultaneous application of these parameters proved useful for the discrimination of different biomass burning events.

The detected L-AAs were mainly L-Ala, L-Glu, L-Arg, L-Val and L-Asp. D-AAs represented $<1 \%$ of the total AAs concentration. D-Ala was observed in all the samples from September to November, while other D-AAs were observed only sporadically, except for the samples collected during biomass burning events. The Student $t$-test confirmed that means of $\mathrm{D} / \mathrm{L}$ ratio values for Asp, Thr, Phe, Ala were significantly higher in samples affected by wildfire or bonfire than those unaffected by such events. Interestingly, we observed high FAA levels during open biomass burning events.

The study of the sources affecting Belgrade aerosols was performed by means of four statistical approaches: CA, PCA, FcA, PMF. All proved to be in good agreement. Better information was obtained by FcA and PMF, which identified five contributing sources: a natural source present in September; a source related to fungi spores and degraded material, mostly present in September-October; and other 3 factors linked to biomass burning: open fire sources (e.g., wildfire); the combustion of grass and agricultural waste (bonfire of leaves, agricultural cuttings) principally present in October and November; and the combustion of biomass in stoves and industrial plants (November and December).

The discrimination of tree different sources of biomass burning, two of them concomitant in October, is an important result. This work suggests an approach to discriminate between concomitant biomass burning events. We used a wide range of specific tracers for wood combustion (anhydro sugars and PCs), fresh vegetal material (e.g., fructose and glucose), fungi (mannitol and arabitol) and degraded material and bacteria (D-AA) present also in soils. These tracers represent a series of compounds from the diverse matrices involved in biomass burning events. Statistical analysis allowed the discrimination of different types of biomass combustion in which the vegetal component is affected by the presence of other matrices.

\section{Acknowledgments}

These results were obtained within the SIMCA project (INTERREG/ CARDS-PHARE Adriatic New Neighborhood Program) grant no. 06SER02/01/04. The present work was supported by the National Research Council of Italy (CNR) and by the ERC advanced grant no 267696 , contribution $n^{\circ} 18$. The authors gratefully acknowledge the help of ELGA LabWater in providing the Chorus system, which produced the ultra-pure water used in these experiments.

\section{Appendix A. Supplementary data}

Materials, description of the analytical methods for PCs, anhydrosugars, L-AAs, D-AAs, sugars determinations and quality control are available. Chromatographic separations of PCs and anhydrosugars are presented in Fig. S1 and S2. Temporal trends for target compounds analyzed are reported in Fig. S3-S14 and back-trajectories in Fig. S15S18. Table S1 presents the summary of theoretical masses of the PCs and anhydrosugars studied; Table S2 reports the analytical performance of the developed methods; Table S3 reports the meteorological data for the sampling campaign and Table S4, the atmospheric concentration for all analytes determined in Belgrade's atmosphere. Supplementary data associated with this article can be found in the online version, at http://dx.doi.org/10.1016/j.scitotenv.2016.06.188.

\section{References}

Akagi, S.K., Yokelson, R.J., Wiedinmyer, C., Alvarado, M.J., Reid, J.S., Karl, T., et al., 2011. Emission factors for open and domestic biomass burning for use in atmospheric models. Atmos. Chem. Phys. 11, 4039-4072. http://dx.doi.org/10.5194/acp-114039-2011.

Amelung, W., Zhang, X., Flach, K.W., 2006. Amino acids in grassland soils: climatic effects on concentrations and chirality. Geoderma 130, 207-217. http://dx.doi.org/10.1016/j. geoderma.2005.01.017.

Barbaro, E., Zangrando, R., Moret, I., Barbante, C., Cescon, P., Gambaro, A., 2011. Free amino acids in atmospheric particulate matter of Venice, Italy. Atmos. Environ. 45, 5050-5057. http://dx.doi.org/10.1016/j.atmosenv.2011.01.068.

Barbaro, E., Zangrando, R., Vecchiato, M., Turetta, C., Barbante, C., Gambaro, A., 2014. Dand L-amino acids in Antarctic lakes: assessment of a very sensitive HPLC-MS method. Anal. Bioanal. Chem. 406, 5259-5270. http://dx.doi.org/10.1007/s00216-0147961-y.

Barbaro, E., Zangrando, R., Vecchiato, M., Piazza, R., Cairns, W., Capodaglio, G., et al., 2015. Free amino acids in Antarctic aerosol: potential markers for the evolution and fate of marine aerosol. Atmos. Chem. Phys. 15, 5457-5469. http://dx.doi.org/10.5194/acp15-5457-2015.

Bari, M.A., Baumbach, G., Kuch, B., Scheffknecht, G., 2009. Wood smoke as a source of particle-phase organic compounds in residential areas. Atmos. Environ. 43, 4722-4732. http://dx.doi.org/10.1016/j.atmosenv.2008.09.006.

Bauer, H., Claeys, M., Vermeylen, R., Schueller, E., Weinke, G., Berger, A., et al., 2008. Arabitol and mannitol as tracers for the quantification of airborne fungal spores. Atmos. Environ. 42, 588-593. http://dx.doi.org/10.1016/j.atmosenv.2007.10.013.

Burshtein, N., Lang-Yona, N., Rudich, Y., 2011. Ergosterol, arabitol and mannitol as tracers for biogenic aerosols in the eastern Mediterranean. Atmos. Chem. Phys. 11, 829-839. http://dx.doi.org/10.5194/acp-11-829-2011.

Calvo, A.I., Alves, C., Castro, A., Pont, V., Vicente, A.M., Fraile, R., 2013. Research on aerosol sources and chemical composition: past, current and emerging issues. Atmos. Res. 120, 1-28. http://dx.doi.org/10.1016/j.atmosres.2012.09.021.

Carmichael, G., Adhikary, B., Kulkarni, S., D'Allura, A., Tang, Y., Streets, D., Zhang, Q., Bond, T., Ramanathan, V., Jamroensan, A., Marrapu, P., 2009. Asian aerosols: current and year 2030 distributions and implications to human health and regional climate change. Environ. Sci. Technol. (43), 5811-5817 http://dx.doi.org/10.1021/es8036803. 
Caseiro, A., Bauer, H., Schmidl, C., Pio, C.A., Puxbaum, H., 2009. Wood burning impact on PM10 in three Austrian regions. Atmos. Environ. 43, 2186-2195. http://dx.doi.org/ 10.1016/j.atmosenv.2009.01.012.

Chen, J., Kawamura, K., Liu, C.Q., Fu, P.Q., 2013. Long-term observations of saccharides in remote marine aerosols from the western North Pacific: a comparison between 1990 and 1993 and 2006-2009 periods. Atmos. Environ. 67, 448-458. http://dx.doi. org/10.1016/j.atmosenv.2012.11.014.

Cowie, G.L., Hedges, J.I., 1992. Sources and reactivities of amino-acids in a coastal marine environment. Limnol. Oceanogr. 37, 703-724.

Dahlman, L., Persson, J., Nasholm, T., Palmqvist, K., 2003. Carbon and nitrogen distribution in the green algal lichens Hypogymnia physodes and Platismatia glauca in relation to nutrient supply. Planta 217, 41-48. http://dx.doi.org/10.1007/s00425-003-0977-8.

Despres, V.R., Huffman, J.A., Burrows, S.M., Hoose, C., Safatov, A.S., Buryak, G., et al., 2012. Primary biological aerosol particles in the atmosphere: a review. Tellus Ser. B Chem. Phys. Meteorol. 64, 58. http://dx.doi.org/10.3402/tellusb.v64i0.15598.

Di Filippo, P., Pomata, D., Riccardi, C., Buiarelli, F., Perrino, C., 2013. Fungal contribution to size-segregated aerosol measured through biomarkers. Atmos. Environ. 64, 132-140. http://dx.doi.org/10.1016/j.atmosenv.2012.10.010.

Di Filippo, P., Pomata, D., Riccardi, C., Buiarelli, F., Gallo, V., Quaranta, A., 2014. Free and combined amino acids in size-segregated atmospheric aerosol samples. Atmos. Environ. 98, 179-189. http://dx.doi.org/10.1016/j.atmosenv.2014.08.069.

Dittmar, T., Fitznar, H.P., Kattner, G., 2001. Origin and biogeochemical cycling of organic nitrogen in the eastern Arctic Ocean as evident from D- and L-amino acids. Geochim. Cosmochim. Acta 65, 4103-4114. http://dx.doi.org/10.1016/S0016-7037(01)006883.

Draxler, R.R., Rolph, G.D., 2012. HYSPLIT (HYbrid Single-Particle Lagrangian Integrated Trajectory); Model Access via NOAA ARL READY Website. NOAA Air Resources Laboratory, Silver Spring, MD.

Elbert, W., Taylor, P.E., Andreae, M.O., Poeschl, U., 2007. Contribution of fungi to primary biogenic aerosols in the atmosphere: wet and dry discharged spores, carbohydrates, and inorganic ions. Atmos. Chem. Phys. 7, 4569-4588. http://dx.doi.org/10.5194/acp7-4569-2007.

Fabbri, D., Torri, C., Simonei, B.R.T., Marynowski, L., Rushdi, A.I., Fabianska, M.J., 2009. Levoglucosan and other cellulose and lignin markers in emissions from burning of Miocene lignites. Atmos. Environ. 43, 2286-2295. http://dx.doi.org/10.1016/j. atmosenv.2009.01.030.

Flanner, M.G., Zender, C.S., Randerson, J.T., Rasch, P.J., 2007. Present-day climate forcing and response from black carbon in snow. J. Geophys. Res.-Atmos. 112. http://dx.doi. org/10.1029/2006JD008003.

Friedman, M., 2010. Origin, microbiology, nutrition, and pharmacology of D-amino acids. Chem. Biodivers. 7, 1491-1530. http://dx.doi.org/10.1002/cbdv.200900225.

Fu, P.Q., Kawamura, K., Kobayashi, M., Simoneit, B.R.T., 2012. Seasonal variations of sugars in atmospheric particulate matter from Gosan, Jeju Island: significant contributions of airborne pollen and Asian dust in spring. Atmos. Environ. 55, 234-239. http://dx.doi. org/10.1016/j.atmosenv.2012.02.061.

Ge, X., Wexler, A.S., Clegg, S.L., 2011. Atmospheric amines - part I. A review. Atmos. Environ. 45, 524-546. http://dx.doi.org/10.1016/j.atmosenv.2010.10.012.

Giannoni, M., Martellini, T., Del Bubba, M., Gambaro, A., Zangrando, R., Chiari, M., et al., 2012. The use of levoglucosan for tracing biomass burning in PM2.5 samples in Tuscany (Italy). Environ. Pollut. 167, 7-15. http://dx.doi.org/10.1016/j.envpol.2012.03. 016.

Glavonjic, B.D., 2011. Consumption of wood fuels in households in Serbia - present state and possible contribution to the climate change mitigation. Therm. Sci. 15, 571-585. http://dx.doi.org/10.2298/TSCI1103571G.

Glavonjic, B.D., Oblak, L.Z., 2012. Consumption of wood fuels in industry, commercial, and pubblic facilities in Serbia - present state and possible contribution to the share of renewable sources in final energy consumption. Therm. Sci. 16, 7-19. http://dx.doi. org/10.2298/TSCI1201007G.

Graham, B., Mayol-Bracero, O.L., Guyon, P., Roberts, G.C., Decesari, S., Facchini, M.C., et al., 2002. Water-soluble organic compounds in biomass burning aerosols over Amazonia - 1. Characterization by NMR and GC-MS. J. Geophys. Res.-Atmos. 107, 16. http://dx. doi.org/10.1029/2001JD000336.

Graham, B., Guyon, P., Taylor, P.E., Artaxo, P., Maenhaut, W., Glovsky, M.M., et al., 2003. Organic compounds present in the natural Amazonian aerosol: characterization by gas chromatography-mass spectrometry. J. Geophys. Res.-Atmos. 108, 13. http://dx. doi.org/10.1029/2003JD003990.

Hobbs, P.V., Reid, J.S., Kotchenruther, R.A., Ferek, R.J., Weiss, R., 1997. Direct radiative forcing by smoke from biomass burning. Science 275, 1776-1778. http://dx.doi.org/10. 1126/science.275.5307.1777.

Jia, Y., Bhat, S., Fraser, M.P., 2010a. Characterization of saccharides and other organic compounds in fine particles and the use of saccharides to track primary biologically derived carbon sources. Atmos. Environ. 44, 724-732. http://dx.doi.org/10.1016/j. atmosenv.2009.10.034.

Jia, Y., Clements, A.L., Fraser, M.P., 2010b. Saccharide composition in atmospheric particulate matter in the southwest US and estimates of source contributions. J. Aerosol Sci. 41, 62-73. http://dx.doi.org/10.1016/j.jaerosci.2009.08.005.

Joliffe, I.T., 2002. Pricipal Component Analysis. second ed. Springer-Verlag, New York.

Kaiser, K., Benner, R., 2008. Major bacterial contribution to the ocean reservoir of detrital organic carbon and nitrogen. Limnol. Oceanogr. 53, 99-112.

Krumal, K., Mikuska, P., Vojtesek, M., Vecera, Z., 2010. Seasonal variations of monosaccharide anhydrides in PM1 and PM2.5 aerosol in urban areas. Atmos. Environ. 44, 5148-5155. http://dx.doi.org/10.1016/j.atmosenv.2010.08.057.

Kuo, L.J., Louchouarn, P., Herbert, B.E., 2011. Influence of combustion conditions on yields of solvent-extractable anhydrosugars and lignin phenols in chars: implications for characterizations of biomass combustion residues. Chemosphere 85, 797-805. http://dx.doi.org/10.1016/j.chemosphere.2011.06.074.
Kuznetsova, M., Lee, C., Aller, J., Frew, N., 2004. Enrichment of amino acids in the sea surface microlayer at coastal and open ocean sites in the North Atlantic Ocean. Limnol. Oceanogr. 49, 1605-1619.

Kuznetsova, M., Lee, C., Aller, J., 2005. Characterization of the proteinaceous matter in marine aerosols. Mar. Chem. 96, 359-377. http://dx.doi.org/10.1016/j.marchem.2005.03. 007.

Lee, E., Chan, C.K., Paatero, P., 1999. Application of positive matrix factorization in source apportionment of particulate pollutants in Hong Kong. Atmos. Environ. 33, 3201-3212. http://dx.doi.org/10.1016/S1352-2310(99)00113-2.

Lemieux, P.M., Lutes, C.C., Santoianni, D.A., 2004. Emissions of organic air toxics from open burning: a comprehensive review. Prog. Energy Combust. Sci. 30, 1-32. http://dx.doi. org/10.1016/j.pecs.2003.08.001.

Mace, K.A., Artaxo, P., Duce, R.A., 2003a. Water-soluble organic nitrogen in Amazon Basin aerosols during the dry (biomass burning) and wet seasons. J. Geophys. Res.-Atmos. 108. http://dx.doi.org/10.1029/2003JD003557.

Mace, K.A., Duce, R.A., Tindale, N.W., 2003b. Organic nitrogen in rain and aerosol at Cape Grim, Tasmania, Australia. J. Geophys. Res.-Atmos. 108. http://dx.doi.org/10.1029/ 2002JD003051.

Mace, K.A., Kubilay, N., Duce, R.A., 2003c. Organic nitrogen in rain and aerosol in the eastern Mediterranean atmosphere: an association with atmospheric dust. J. Geophys. Res.-Atmos. 108. http://dx.doi.org/10.1029/2002JD002997.

Mandalakis, M., Apostolaki, M., Tziaras, T., Polymenakou, P., Stephanou, E.G., 2011. Free and combined amino acids in marine background atmospheric aerosols over the Eastern Mediterranean. Atmos. Environ. 45, 1003-1009. http://dx.doi.org/10.1016/j. atmosenv.2010.10.046.

Manninen, H.E., Back, J., Sihto-Nissila, S.-L., Huffman, J.A., Pessi, A.-M., Hiltunen, V., et al., 2014. Patterns in airborne pollen and other primary biological aerosol particles (PBAP), and their contribution to aerosol mass and number in a boreal forest. Boreal Environ. Res. 19, 383-405.

Matrai, P.A., Tranvik, L., Leck, C., Knulst, J.C., 2008. Are high Arctic surface microlayers a potential source of aerosol organic precursors? Mar. Chem. 108, 109-122. http://dx.doi. org/10.1016/j.marchem.2007.11.001.

Matsumoto, K., Uematsu, M., 2005. Free amino acids in marine aerosols over the western North Pacific Ocean. Atmos. Environ. 39, 2163-2170. http://dx.doi.org/10.1016/j. atmosenv.2004.12.022

McCarthy, M.D., Hedges, J.I., Benner, R., 1998. Major bacterial contribution to marine dissolved organic nitrogen. Science 281, 231-234. http://dx.doi.org/10.1126/science. 281.5374.231.

McGregor, K.G., Anastasio, C., 2001. Chemistry of fog waters in California's Central Valley: 2. Photochemical transformations of amino acids and alkyl amines. Atmos. Environ. 35, 1091-1104. http://dx.doi.org/10.1016/S1352-2310(00)00282-X.

Medeiros, P.M., Simoneit, B.R.T., 2007. Analysis of sugars in environmental samples by gas chromatography-mass spectrometry. J. Chromatogr. A 1141, 271-278. http://dx.doi. org/10.1016/j.chroma.2006.12.017.

Medeiros, P.M., Simoneit, B.R.T., 2008. Source profiles of organic compounds emitted upon combustion of green vegetation from temperate climate forests. Environ. Sci. Technol. 42, 8310-8316. http://dx.doi.org/10.1021/es801533b.

Medeiros, P.M., Conte, M.H., Weber, J.C., Simoneit, B.R.T., 2006. Sugars as source indicators of biogenic organic carbon in aerosols collected above the Howland Experimental Forest, Maine. Atmos. Environ. 40, 1694-1705. http://dx.doi.org/10.1016/j. atmosenv.2005.11.001.

Naeher, L.P., Brauer, M., Lipsett, M., Zelikoff, J.T., Simpson, C.D., Koenig, J.Q., et al., 2007. Woodsmoke health effects: a review. Inhal. Toxicol. 19, 67-106. http://dx.doi.org/ $10.1080 / 08958370600985875$.

NASA, d. NASA Earth Observationshttp://neo.sci.gsfc.nasa.gov/view.php?datasetId= MOD14A1_M_FIRE.

Novakov, T., Corrigan, C.E., 1996. Cloud condensation nucleus activity of the organic component of biomass smoke particles. Geophys. Res. Lett. 23, 2141-2144. http://dx.doi. org/10.1029/96GL01971.

Opsahl, S., Benner, R., 1998. Photochemical reactivity of dissolved lignin in river and ocean waters. Limnol. Oceanogr. 43, 1297-1304. http://dx.doi.org/10.4319/lo.1998.43.6. 1297.

Oros, D.R., bin Abas, M.R., Omar, N., Rahman, N.A., Simoneit, B.R.T., 2006. Identification and emission factors of molecular tracers in organic aerosols from biomass burning: part 3. Grasses. Appl. Geochem. 21, 919-940. http://dx.doi.org/10.1016/j.apgeochem. 2006.01.008.

Oros, D.R., Simoneit, B.R.T., 2001a. Identification and emission factors of molecular tracers in organic aerosols from biomass burning part 1. Temperate climate conifers. Appl. Geochem. 16, 1513-1544. http://dx.doi.org/10.1016/S0883-2927(01)00021-X.

Oros, D.R., Simoneit, B.R.T., 2001b. Identification and emission factors of molecular tracers in organic aerosols from biomass burning part 2. Deciduous trees. Appl. Geochem. 16, 1545-1565. http://dx.doi.org/10.1016/S0883-2927(01)00022-1.

Paatero, P., 1997. Least squares formulation of robust non-negative factor analysis. Chemom. Intell. Lab. Syst. 37, 23-35. http://dx.doi.org/10.1016/S01697439(96)00044-5.

Paatero, P., Hopke, P.K., 2003. Discarding or downweighting high-noise variables in factor analytic models. Anal. Chim. Acta 490, 277-289. http://dx.doi.org/10.1016/S00032670(02)01643-4.

Paatero, P., Tapper, U., 1994. Positive matrix factorization: a non-negative factor model with optimal utilization of error estimates of data values. Environmetrics 5 111-126. http://dx.doi.org/10.1002/env.3170050203.

Pashynska, V., Vermeylen, R., Vas, G., Maenhaut, W., Claeys, M., 2002. Development of a gas chromatographic/ion trap mass spectrometric method for the determination of levoglucosan and saccharidic compounds in atmospheric aerosols. Application to urban aerosols. J. Mass Spectrom. 37, 1249-1257. http://dx.doi.org/ $10.1002 / j m s .391$. 
Perrone, M.G., Larsen, B.R., Ferrero, L., Sangiorgi, G., De Gennaro, G., Udisti, R., et al., 2012. Sources of high PM2.5 concentrations in Milan, Northern Italy: molecular marker data and CMB modelling. Sci. Total Environ. 414, 343-355. http://dx.doi.org/10. 1016/j.scitotenv.2011.11.026.

Piazzalunga, A., Belis, C., Bernardoni, V., Cazzuli, O., Fermo, P., Valli, G., et al., 2011. Estimates of wood burning contribution to PM by the macro-tracer method using tailored emission factors. Atmos. Environ. 45, 6642-6649. http://dx.doi.org/10.1016/j. atmosenv.2011.09.008.

Piazzalunga, A., Anzano, M., Collina, E., Lasagni, M., Lollobrigida, F., Pannocchia, A., et al., 2013. Contribution of wood combustion to PAH and PCDD/F concentrations in two urban sites in Northern Italy. J. Aerosol Sci. 56, 30-40. http://dx.doi.org/10.1016/j. jaerosci.2012.07.005.

Pietrogrande, M.C., Bacco, D., Visentin, M., Ferrari, S., Casali, P., 2014. Polar organic marker compounds in atmospheric aerosol in the Po Valley during the Supersito campaigns part 2: seasonal variations of sugars. Atmos. Environ. 97, 215-225. http://dx.doi.org/ 10.1016/j.atmosenv.2014.07.056.

Pio, C.A., Legrand, M., Alves, C.A., Oliveira, T., Afonso, J., Caseiro, A., et al., 2008. Chemica composition of atmospheric aerosols during the 2003 summer intense forest fire period. Atmos. Environ. 42, 7530-7543. http://dx.doi.org/10.1016/j.atmosenv.2008.05. 032.

Poeschl, U., Martin, S.T., Sinha, B., Chen, Q., Gunthe, S.S., Huffman, J.A., et al., 2010 Rainforest aerosols as biogenic nuclei of clouds and precipitation in the Amazon. Science 329, 1513-1516. http://dx.doi.org/10.1126/science.1191056.

Ramanathan, V., Carmichael, G., 2008. Global and regional climate changes due to black carbon. Nat. Geosci. 1, 221-227. http://dx.doi.org/10.1038/ngeo156.

Samburova, V., Hallar, A.G., Mazzoleni, L.R., Saranjampour, P., Lowenthal, D., Kohl, S.D., et al., 2013. Composition of water-soluble organic carbon in non-urban atmospheric aerosol collected at the Storm Peak Laboratory. Environ. Chem. 10, 370-380. http:// dx.doi.org/10.1071/EN13079.

Samy, S., Robinson, J., Rumsey, I.C., Walker, J.T., Hays, M.D., 2013. Speciation and trends of organic nitrogen in southeastern US fine particulate matter (PM2.5). J. Geophys. Res.Atmos. 118, 1996-2006. http://dx.doi.org/10.1029/2012JD017868.

Sang, X., Zhang, Z., Chan, C., Engling, G., 2013. Source categories and contribution of biomass smoke to organic aerosol over the southeastern Tibetan Plateau. Atmos. Environ. 78, 113-123. http://dx.doi.org/10.1016/j.atmosenv.2012.12.012.

Scalabrin, E., Zangrando, R., Barbaro, E., Kehrwald, N.M., Gabrieli, J., Barbante, C., et al 2012. Amino acids in Arctic aerosols. Atmos. Chem. Phys. 12, 10453-10463. http:// dx.doi.org/10.5194/acp-12-10453-2012.

Scheller, E., 2001. Amino acids in dew - origin and seasonal variation. Atmos. Environ. 35 2179-2192. http://dx.doi.org/10.1016/S1352-2310(00)00477-5.

Schmidl, C., Bauer, H., Dattler, A., Hitzenberger, R., Weissenboeck, G., Marr, I.L., et al., 2008a. Chemical characterisation of particle emissions from burning leaves. Atmos. Environ. 42, 9070-9079. http://dx.doi.org/10.1016/j.atmosenv.2008.09.010.

Schmidl, C., Marr, L.L., Caseiro, A., Kotianova, P., Berner, A., Bauer, H., et al., 2008b. Chemical characterisation of fine particle emissions from wood stove combustion of common woods growing in mid-European Alpine regions. Atmos. Environ. 42, 126-141. http://dx.doi.org/10.1016/j.atmosenv.2007.09.028.

Simoneit, B.R.T., 2002. Biomass burning - a review of organic tracers for smoke from incomplete combustion. Appl. Geochem. 17, 129-162. http://dx.doi.org/10.1016/ S0883-2927(01)00061-0.

Simoneit, B.R.T., Elias, V.O., Kobayashi, M., Kawamura, K., Rushdi, A.I., Medeiros, P.M., et al 2004. Sugars - dominant water-soluble organic compounds in soils and characterization as tracers in atmospheric particulate matter. Environ. Sci. Technol. 38 5939-5949. http://dx.doi.org/10.1021/es0403099.

Simpson, C.D., Paulsen, M., Dills, R.L., Liu, L.J.S., Kalman, D.A., 2005. Determination of methoxyphenols in ambient atmospheric particulate matter: tracers for wood combustion. Environ. Sci. Technol. 39, 631-637. http://dx.doi.org/10.1021/es0486871.

Sommerville, K., Preston, T., 2001. Characterisation of dissolved combined amino acids in marine waters. Rapid Commun. Mass Spectrom. 15, 1287-1290. http://dx.doi.org/10. $1002 / \mathrm{rcm} .302$

Stocker, T.F., Qui, D., Plattner, G.K., Tignor, M., Allen, S.K., Boschung, J., Nauels, A., Xia, Y., Bex, V., Midgley, P.M., 2013. In: IPCC, 2013, Climate Change 2013 (Eds.), The Physical
Science Basis. Contribution of Working Group I to the Fifth Assessment Report of the Intergovernmental Panel on Climate Change. 1535, (Cambridge, United Kingdom and New York, NY, USA).

Taylor, D., 2010. Biomass burning, humans and climate change in Southeast Asia. Biodivers. Conserv. 19, 1025-1042. http://dx.doi.org/10.1007/s10531-009-9756-6.

Torres-Duque, C., Maldonado, D., Perez-Padilla, R., Ezzati, M., Viegi, G., Forum of International Respiratory Studies Task Force on H, et al., 2008. Biomass fuels and respiratory diseases: a review of the evidence. Proc. Am. Thorac. Soc. 5, 577-590.

van Drooge, B.L., Fontal, M., Bravo, N., Fernandez, P., Fernandez, M.A., Munoz-Arnanz, J., et al., 2014. Seasonal and spatial variation of organic tracers for biomass burning in PM1 aerosols from highly insolated urban areas. Environ. Sci. Pollut. Res. 21, 11661-11670. http://dx.doi.org/10.1007/s11356-014-2545-0.

Vestin, A., Rissler, J., Swietlicki, E., Frank, G.P., Andreae, M.O., 2007. Cloud-nucleating properties of the Amazonian biomass burning aerosol: cloud condensation nuclei measurements and modeling. J. Geophys. Res.-Atmos. 112, D14201. http://dx.doi.org/10. 1029/2006JD008104.

Viana, M., Kuhlbusch, T.A.J., Querol, X., Alastuey, A., Harrison, R.M., Hopke, P.K., et al., 2008. Source apportionment of particulate matter in Europe: a review of methods and results. J. Aerosol Sci. 39, 827-849. http://dx.doi.org/10.1016/j.jaerosci.2008.05.007.

Vojkan, G., Bojana, T., 2013. Spatial and temporal analysis of fires in Serbia for period 2000-2013. Journal of the Geographical Institute Jovan Cvijic. 63.SASA, pp. 297-312 http://dx.doi.org/10.2298/IJGI1303297G

Vranova, V., Zahradnickova, H., Janous, D., Skene, K.R., Matharu, A.S., Rejsek, K., et al., 2012. The significance of D-amino acids in soil, fate and utilization by microbes and plants: review and identification of knowledge gaps. Plant Soil 354, 21-39. http://dx.doi.org/ $10.1007 / \mathrm{s} 11104-011-1059-5$.

Ward, T.J., Hamilton, R.F., Dixon, R.W., Paulsen, M., Simpson, C.D., 2006. Characterization and evaluation of smoke tracers in PM: results from the 2003 Montana wildfire season. Atmos. Environ. 40, 7005-7017. http://dx.doi.org/10.1016/j.atmosenv.2006.06. 034.

Ward, T.J., Palmer, C.P., Bergauff, M., Jayanty, R.K.M., Noonan, C.W., 2011. Organic/elemental carbon and woodsmoke tracer concentrations following a community wide woodstove changeout program. Atmos. Environ. 45, 5554-5560. http://dx.doi.org/10.1016/ j.atmosenv.2011.05.005.

Wedyan, M.A., Preston, M.R., 2008. The coupling of surface seawater organic nitrogen and the marine aerosol as inferred from enantiomer-specific amino acid analysis. Atmos. Environ. 42, 8698-8705. http://dx.doi.org/10.1016/j.atmosenv.2008.04.038.

Yan, G., Kim, G., Kim, J., Jeong, Y.-S., Il, K.Y., 2015. Dissolved total hydrolyzable enantiomeric amino acids in precipitation: implications on bacterial contributions to atmospheric organic matter. Geochim. Cosmochim. Acta 153, 1-14. http://dx.doi.org/10. 1016/j.gca.2015.01.005.

Yang, H., Yu, J.Z., Ho, S.S.H., Xu, J.H., Wu, W.S., Wan, C.H., et al., 2005. The chemical composition of inorganic and carbonaceous materials in PM2.5 in Nanjing, China. Atmos. Environ. 39, 3735-3749. http://dx.doi.org/10.1016/j.atmosenv.2005.03.010.

Yang, Y.H., Chan, C.Y., Tao, J., Lin, M., Engling, G., Zhang, Z.S., et al., 2012. Observation of elevated fungal tracers due to biomass burning in the Sichuan Basin at Chengdu City, China. Sci. Total Environ. 431, 68-77. http://dx.doi.org/10.1016/j.scitotenv. 2012.05.033.

Yttri, K.E., Dye, C., Slordal, L.H., Braathen, O.A., 2005. Quantification of monosaccharide anhydrides by liquid chromatography combined with mass spectrometry: application to aerosol samples from an urban and a suburban site influenced by small-scale wood burning. J. Air Waste Manage. Assoc. 55, 1169-1177. http://dx.doi.org/10. 1080/10473289.2005.10464720.

Yttri, K.E., Dye, C., Kiss, G., 2007. Ambient aerosol concentrations of sugars and sugaralcohols at four different sites in Norway. Atmos. Chem. Phys. 7, 4267-4279. http:// dx.doi.org/10.5194/acp-7-4267-2007.

Zhang Q., Anastasio, C. 2003. Free and combined amino compounds in atmospheric fine particles (PM2.5) and fog waters from Northern California. Atmos. Environ. 37, 2247-2258. http://dx.doi.org/10.1016/S1352-2310(03)00127-4. 